$10 / 18.940 .00$

SANDIA REPORT

SAND94-0981 - UC-2010

Unlimited Release

Printed September 1994

\title{
Ranking of Septic Tank and Drainfield Sites Using Travel Time to the Groundwater Table
}

Brenda S. Langkopf, James T. McCord

Propared by

Sandla National Laboratorles

Albuquerque, Now Mexico 87185 and Livermore, Callfornia 94550 for the United States Department of Energy

under Contract DE-ACO4-94AL85000

Approved for public release; distribution is unlimited. 
Issued by Sandia National Laboratories, operated for the United States Department of Energy by Sandia Corporation.

NOTICE: This report was prepared as an account of work sponsored by an agency of the United States Government. Neither the United States Government nor any agency thereof, nor any of their employees, nor any of their contractors, subcontractors, or their employees, makes any warranty, express or implied, or assumes any legal liability or responsibility for the accuracy, completeness, or usefulness of any information, apparatus, product, or process disclosed, or represents that its use would not infringe privately owned rights. Reference herein to any specific commercial product, process, or service by trade name, trademark, manufacturer, or otherwise, does not necessarily constitute or imply its endorsement, recommendation, or favoring by the United States Government, any agency thereof or any of their contractors or subcontractors. The views and opinions expressed herein do not necessarily state or reflect those of the United States Government, any agency thereof or any of their contractors.

Printed in the United States of America. This report has been reproduced directly from the best available copy.

Available to DOE and DOE contractors from Office of Scientific and Technical Information

PO Box 62

Oak Ridge, TN 37831

Prices available from (615) 576-8401, FTS 626-8401

Available to the public from

National Technical Information Service

US Department of Commerce

5285 Port Royal Rd

Springfield, VA 22161

NTIS price codes

Printed copy: A04

Microfiche copy: A01 


\section{DISCLAIMER}

Portions of this document may be illegible in electronic image products. Images are produced from the best available original document. 


\title{
RANKING OF SEPTIC TANK AND DRAINFIELD SITES USING TRAVEL TIME TO THE GROUNDWATER TABLE
}

\author{
Brenda S. Langkopf and James T. McCord \\ Environmental Risk Assessment and Risk Management Department \\ Sandia National Laboratories \\ Albuquerque, New Mexico 87185
}

\begin{abstract}
The Environmental Restoration Program at Sandia National Laboratories, New Mexico (SNL/NM) is tasked with performing assessments and cleanup of waste sites that belong to SNL. SNL's waste sites are divided into several activities. Septic Tanks and Drainfields (STD) is an activity that includes 23 different sites at SNL/NM. All these sites may have released hazardous wastes into the soil from drains or sewers of buildings. The STD sites must be assessed and, if necessary, remediated according to the Resource Conservation and Recovery Act (RCRA) Corrective Action process. A modeling study has been completed to help prioritize the sites for future field investigation based on the risk that each site may pose to human health and the environment. Two of the influences on the risk to human health and environment are addressed in this study - the fluid disposal volume and groundwater depth. These two parameters, as well as several others, were used as input into a computer model to calculate groundwater travel time to the water table. The computer model was based on Darcy's Law and a simple mass balance. To account for uncertainty in the input parameters, a Monte Carlo approach was used to determine the travel times; 1000 realizations were completed to determine the travel time for each site. The range assigned to each of the input parameters was sampled according to an assigned statistical distribution using the Latin Hypercube Method to arrive at input for the calculations. The groundwater travel times resulting from these calculations were used to rank the sites for future field investigation.
\end{abstract}




\section{CONTENTS}

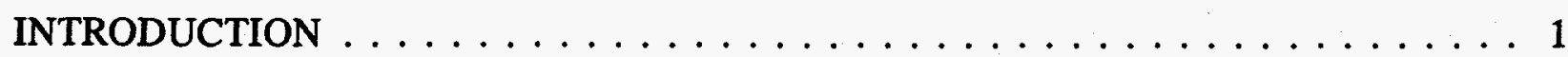

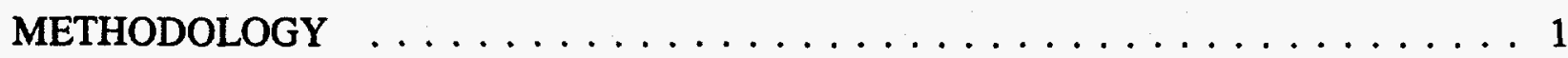

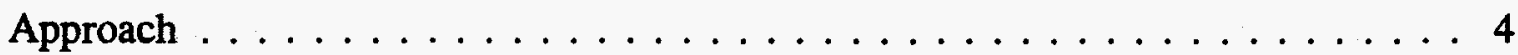

Application to Seepage Pit and Drainfield Sites ..............4

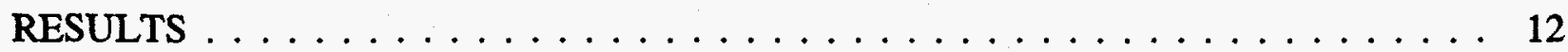

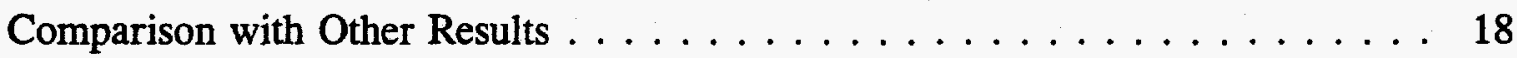

SUMMARY AND CONCLUSIONS $\ldots \ldots \ldots \ldots \ldots \ldots \ldots \ldots \ldots$

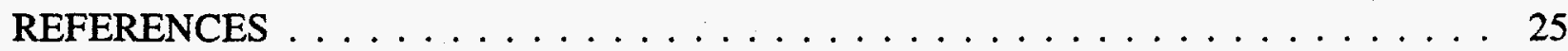

APPENDIX A: Program Listing for the Mass Balance Calculations when Velocity IS NOT Limited by Saturated Hydraulic Conductivity . . . . . . . . . . . . . 27

APPENDIX B: Program Listing for the Mass Balance Calculations when Velocity IS Limited by Saturated Hydraulic Conductivity . . . . . . . . . . . . . 35

\section{FIGURES}

1. Septic Tanks and Drainfields Site Location Map . . . . . . . . . . . 3

2. Schematic of Flow to the Groundwater Table $\ldots \ldots \ldots \ldots \ldots$

3. Tension Head Versus Volumetric Moisture Content and Hydraulic Conductivity (K) Versus Tension Head $\ldots \ldots \ldots \ldots \ldots \ldots \ldots \ldots$

4. Results of Lilliefors Statistical Test for Normalcy (Iman and Conover, 1983) with $95 \%$ Confidence Bounds Displayed $\ldots \ldots \ldots \ldots \ldots \ldots$

5. Example Sample Distribution for Number of People when There Are Full-Time and Occasional People (site 148 is given as the example) . . . . . . . . . . 9

6. Minimum, Maximum, and Arithmetic Mean of Water Usage Rate for All Calculations Completed (ordered by geometry and mean water usage rate) $\ldots \ldots \ldots \ldots 9$

7. Seepage Pit Diagram and Equation for Travel Time to the Water Table $\ldots \ldots \ldots 11$

8. Minimum, Maximum, and Arithmetic Mean of Depth to the Water Table for All Calculations Completed (ordered by geometry and depth to the water table) ... 12 


\section{FIGURES (CONCLUDED)}

9. Minimum, Maximum, and Arithmetic Mean of the Travel Time for Septic Tank and Drainfield Sites when the Velocity Is NOT Limited by the Saturated Hydraulic Conductivity (ordered by site number) $\ldots \ldots \ldots \ldots \ldots \ldots \ldots \ldots$

10. Minimum, Maximum, and Arithmetic Mean of the Travel Time for Septic Tank and Drainfield Site when Velocity IS Limited by Saturated Hydraulic Conductivity (ordered by site number) $\ldots \ldots \ldots \ldots \ldots \ldots \ldots \ldots \ldots \ldots \ldots$

11. Minimum, Maximum, and Arithmetic Mean of the Travel Time for Septic Tank and Drainfield Site when Velocity Is NOT Limited by Saturated Hydraulic Conductivity (ordered by mean travel time) $\ldots \ldots \ldots \ldots \ldots \ldots$

12. Minimum, Maximum, and Arithmetic Mean of the Travel Time for Septic Tank and Drainfield Site when Velocity IS Limited by Saturated Hydraulic

Conductivity (ordered by mean travel time) $\ldots \ldots \ldots \ldots \ldots 16$

13. Minimum, Maximum, and Arithmetic Mean of the Travel Time for Septic Tank and Drainfield Sites when Velocity Is NOT Limited by Saturated Hydraulic Conductivity (ordered by geometry and mean travel time) $\ldots \ldots \ldots \ldots \ldots$

14. Minimum, Maximum and Arithmetic Mean of the Travel Time for the Septic Tank and Drainfields Site When Velocity IS Limited by Saturated Hydraulic Conductivity (ordered by geometry and mean travel time) $\ldots \ldots \ldots \ldots$

15. Ranking and the Minimum, Maximum, and Arithmetic Mean of the Travel Time for Seepage Pit and Drainfield Sites (ordered by mean travel time) . . . . . . . 19

16. Ranking and the Minimum, Maximum, and Arithmetic Mean of the Travel Time for Seepage Pit and Drainfield Sites (ordered by geometry and mean travel time) . . 19

17. Ranking and the Minimum, Maximum, and Arithmetic Mean of the Travel Time for Seepage Pit and Drainfield Sites (ordered by the site number) $\ldots \ldots \ldots 20$

18. Example of the Two-Dimensional Spatial Variation in Hydraulic Conductivity

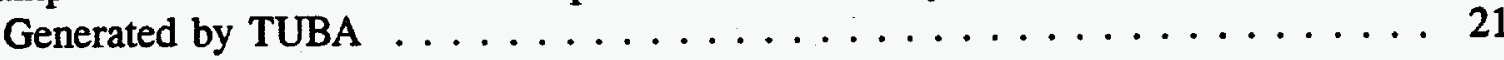

19. Comparison of VS2DT and Mass Balance Travel Time Results for a Water Usage

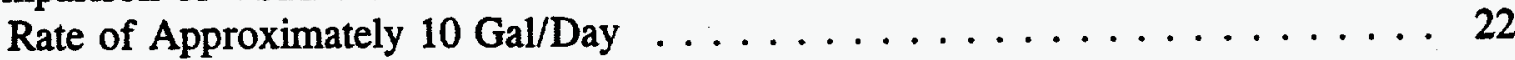

20. Comparison of VS2DT and Mass Balance Travel Time Results for a Water Usage

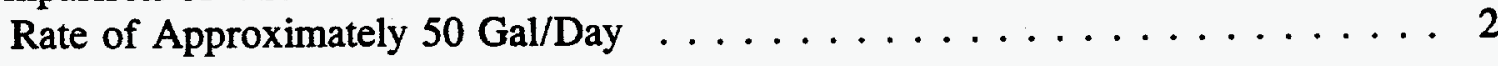




\section{TABLES}

1. Brief Description of STD Sites $\ldots \ldots \ldots \ldots \ldots \ldots \ldots \ldots \ldots \ldots \ldots \ldots \ldots$

2. Description of Site-Specific Input Parameters $\ldots \ldots \ldots \ldots \ldots$

3. Travel Time to the Groundwater Table when Velocity IS NOT Limited by Saturated Hydraulic Conductivity $\ldots \ldots \ldots \ldots \ldots \ldots \ldots \ldots$

4. Range of Calculated Travel Times to the Groundwater Table when Velocity IS

Limited by Saturated Hydraulic Conductivity $\ldots \ldots \ldots \ldots \ldots 14$ 


\title{
NOMENCLATURE
}

\author{
DF Drainfield \\ DF + SP Drainfield plus seepage pit \\ KAFB Kirtland Air Force Base \\ RCRA Resource Conservation and Recovery Act \\ RFI RCRA Facility Investigation \\ SNL/NM Sandia National Laboratories, New Mexico \\ SP Seepage Pit \\ STD Septic Tanks and Drainfields \\ TUBA Turning Bands Algorithm
}




\section{Ranking of Septic Tank and Drainfield Sites Using Travel Time to the Groundwater Table}

\section{INTRODUCTION}

The Environmental Restoration Program at Sandia National Laboratories, New Mexico (SNL/NM) is tasked with performing assessments and cleanup of inactive waste sites. This program formally started in 1984 when the U.S. Department of Energy began identifying potential hazardous waste sites. The programs in place today, including the analyses described here, have expanded these first efforts.

SNL/NM waste sites have been divided into several activities. The Septic Tanks and Drainfields (STD) activity includes 23 different sites located in remote areas at SNL/NM. Table 1 provides a brief description of these sites, and Figure 1 shows their locations. All these sites may have released hazardous wastes into the soil from drains or sewers of buildings. The waste, potentially, would have been released into either drainfields or seepage pits similar to domestic septic systems.

The STD sites must be assessed and, if necessary, remediated in accordance with the Resource Conservation and Recovery Act (RCRA) corrective action process. To meet this objective, each site will be investigated in sufficient detail to determine the potential risks to human and environmental health as a result of a possible contaminant release into the seepage pits and drainfields. Because we cannot investigate all the sites at once, we must set some sequential ordering scheme, or prioritization, for conducting the field work. Therefore, we have performed a quantitative analysis of the travel time to the groundwater table at the STD sites. The results have been used to prioritize the sites for field work. Additionally, the information derived from the preliminary quantitative analysis will help to identify sites that are likely to require groundwater monitoring networks. This report addresses the development and application of the quantitative approach used to rank the sites for field work.

\section{METHODOLOGY}

The primary idea underlying the ranking approach is that we should first investigate the sites that pose the most risk to human health and the environment and work our way down to the lower risk sites. The problem is to quantify the risks and subsequently rank the sites based on this quantification.

The risk posed by each site depends on several criteria, including, but not limited to, (1) the principal contaminants, (2) the volume of contaminants and fluids disposed of, (3) the flow and transport characteristics of the contaminants through the site-specific geologic media, (4) the depth to groundwater, and (5) the proximity to receptors. Given the very limited site-specific data based on facility use derived from staff interviews and SNL/NM records, there is a great deal of uncertainty in our knowledge of the risk associated with the first three criteria. The knowledge of the groundwater hydrology is also limited and casts uncertainty on the last three criteria. This dictated that we develop a highly simplified and conservative approach toward preliminary risk quantification. It also suggested that 
TABLE 1. Brief Description of STD Sites

\begin{tabular}{|c|l|c|}
\hline Site \# & Location Description & Initial Service Date \\
\hline 49 & Bldg 9820, Photometrics/ Machine Shop & 1958 \\
\hline 101 & Bldg 9926, Explosive Research Laboratory & 1958 \\
\hline 116 & Bldg 9990, Electroexplosive Research Facility & 1969 \\
\hline 137 & Bldg 6540/6542, Photometrics Building & 1959 \\
\hline 138 & Bldg 6630, Climatic Test Facility & 1959 \\
\hline 139 & Bldg 9964, Instrument Building for Shock Facility & 1965 \\
\hline 140 & Bldg 9965, Remote Control Building for Shock Facility & 1965 \\
\hline 141 & Bldg 9967, High Explosive Assembly Building & 1968 \\
\hline 142 & Bldg 9970, Antenna Measurement Facility & 1963 \\
\hline 143 & Bldg 9972, EMP Studies Facility A & 1987 \\
\hline 144 & Bldg 9980, Solar Power Tower & 1976 \\
\hline 145 & Bldgs 9981/9982, 5-MW Solar Control Building/ & 1976 \\
\hline & &.- \\
\hline 146 & Bldg 9920, Explosive Test Facility & 1958 \\
\hline 147 & Bidg 9925, Coyote Test Field Headquarters & 1959 \\
\hline 148 & Bldg 9927, Explosive Test Facility & 1962 \\
\hline 149 & Bldg 9930, Explosive \& Test Lab Building & 1961 \\
\hline 150 & Bldgs 9939, 9939A, Evaluation Explosive Facility & $1967 \& 1978$ \\
\hline & Control Building & - \\
\hline 151 & Bldg 9940, Explosive Test Facility & 1962 \\
\hline 152 & Bldg 9950, Materials Test Facility & 1964 \\
\hline 153 & Bidg 9956, Intermediate Velocity Gun Facility & 1969 \\
\hline 154 & Bldg 9960, Explosive Preparation Facility & 1965 \\
\hline 160 & Bldg 9832, Vehicle Assembly Building & 1968 \\
\hline 161 & Bidg 6636, Non-destructive Test Facility & 1971 \\
\hline
\end{tabular}




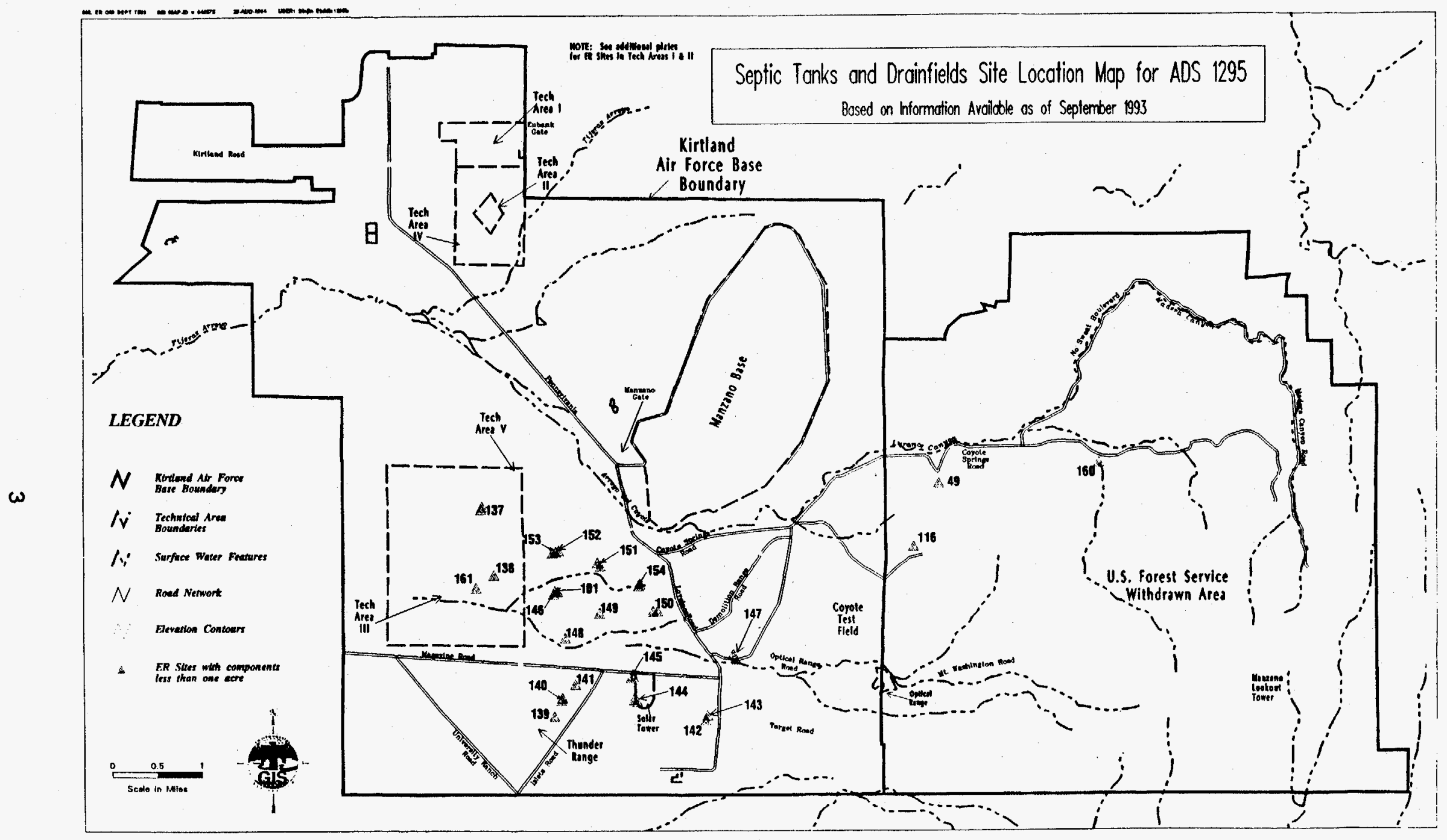

FIGURE 1. Septic Tanks and Drainfields Site Location Map 
risks derived from this approach should be considered relative and not absolute.

In this study, we have used groundwater travel time from the source to the groundwater table to rank the relative risks of the sites. Thus, this study addresses two of the five criteria listed above: depth to the groundwater table and chemically unreactive flow through the site-specific geologic media.

\section{Approach}

To provide a quantitative estimate of effective travel time through the vadose zone to the water table, we employed a simple mass balance approach and Darcy's Law. As shown in Figure 2, we used the following four basic parameters to estimate the effective travel time: an estimation of discharge rate to the septic system, Q; the cross-sectional area of the geologic media wetted by the effluent, $A$; the porosity of the wetted media, $\mathrm{n}$; and the depth to groundwater, $D_{w t}$. As a first pass, we assumed that the vadose zone was uniformly saturated by the septic discharge and that the media were able to transport the discharge at the assumed rate of release. To obtain the average linear velocity, or seepage velocity of the fluid, $v_{s}$, we divided the Darcy velocity, $v_{d}$, by the moisture content:

$$
\mathbf{v}_{\mathbf{s}}=\mathbf{v}_{\mathrm{d}} / \mathbf{n}=\mathrm{Q} / \mathrm{A} / \mathbf{n}
$$

The effective travel time through the vadose zone to the water table, $t_{\text {vadose }}$, would be:

$$
\mathrm{t}_{\mathrm{vadose}}=\mathrm{D}_{\mathrm{wr}} / \mathrm{v}_{\mathrm{s}}=\mathrm{D}_{\mathrm{wr}} /(\mathrm{Q} / \mathrm{A} / \mathrm{n})
$$

According to Darcy's Law, $v_{d}=K \cdot$ gradient . If the media are uniformly wetted, with gravity as the only driving force, the gradient will approach unity, and the associated vertical Darcy velocity will approach the saturated hydraulic conductivity, $\mathrm{K}_{\mathrm{s}}$, of the medium. For any medium, the maximum hydraulic conductivity will be the saturated hydraulic conductivity, $\mathrm{K}_{\mathrm{s}}$; the hydraulic conductivity decreases as the moisture content decreases and tension head increases (Figure 3). Thus, in our second pass at the calculations, two velocities were compared: one calculated using $Q$ and the other, $K_{s}$ sampled from a range of SNL/NM saturated hydraulic conductivities. The smaller of these two values was used as the seepage velocity.

Appendix A lists the computer program used in the first pass, and Appendix B lists the program used in the second pass.

\section{Application to Seepage Pit and Drainfield Sites}

Because of the uncertainty in the input parameters, a Monte Carlo approach was used to estimate the travel times; 1000 realizations were completed to determine the travel time for each set of site parameters. The approach described in the document, $A$ FORTRAN 77 Program and User's Guide for the Generation of Latin Hypercube and Random Samples for Use with Computer Models (Iman and Shortencarier, 1984), was used to arrive at the data used for input in these realizations. The remainder of this section identifies the input data used in the travel time calculations, and the bounds and sample distribution of the input data that were input into the Latin hypercube program to arrive at the data sets for the 1000 realizations. 


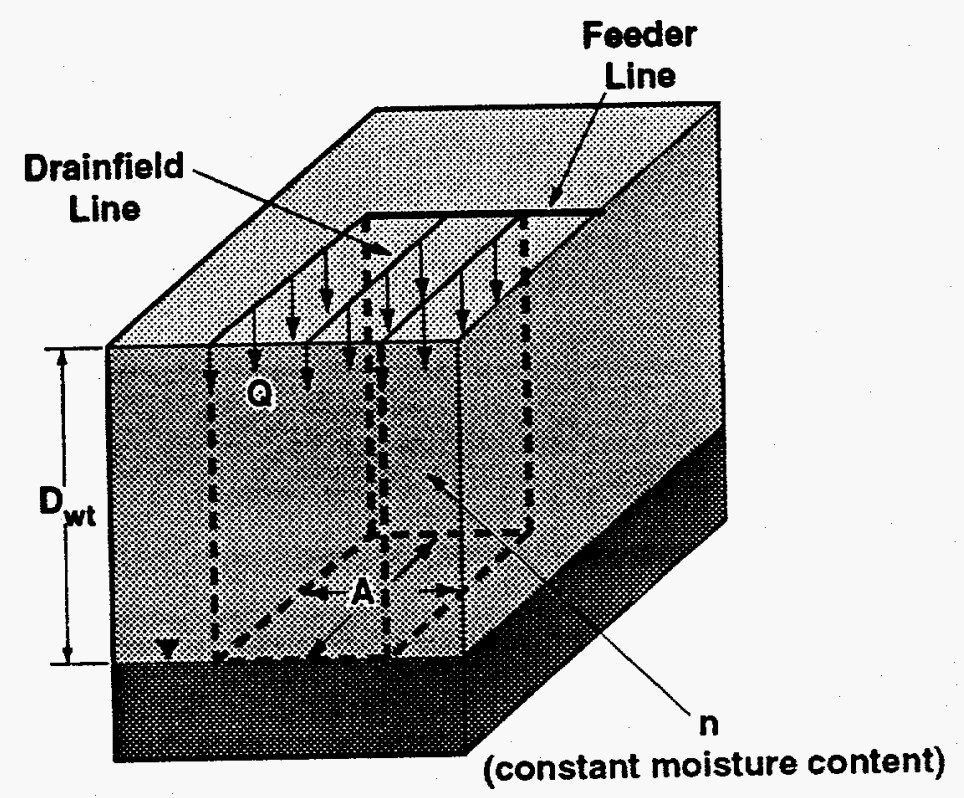

FIGURE 2. Schematic of Flow to the Groundwater Table
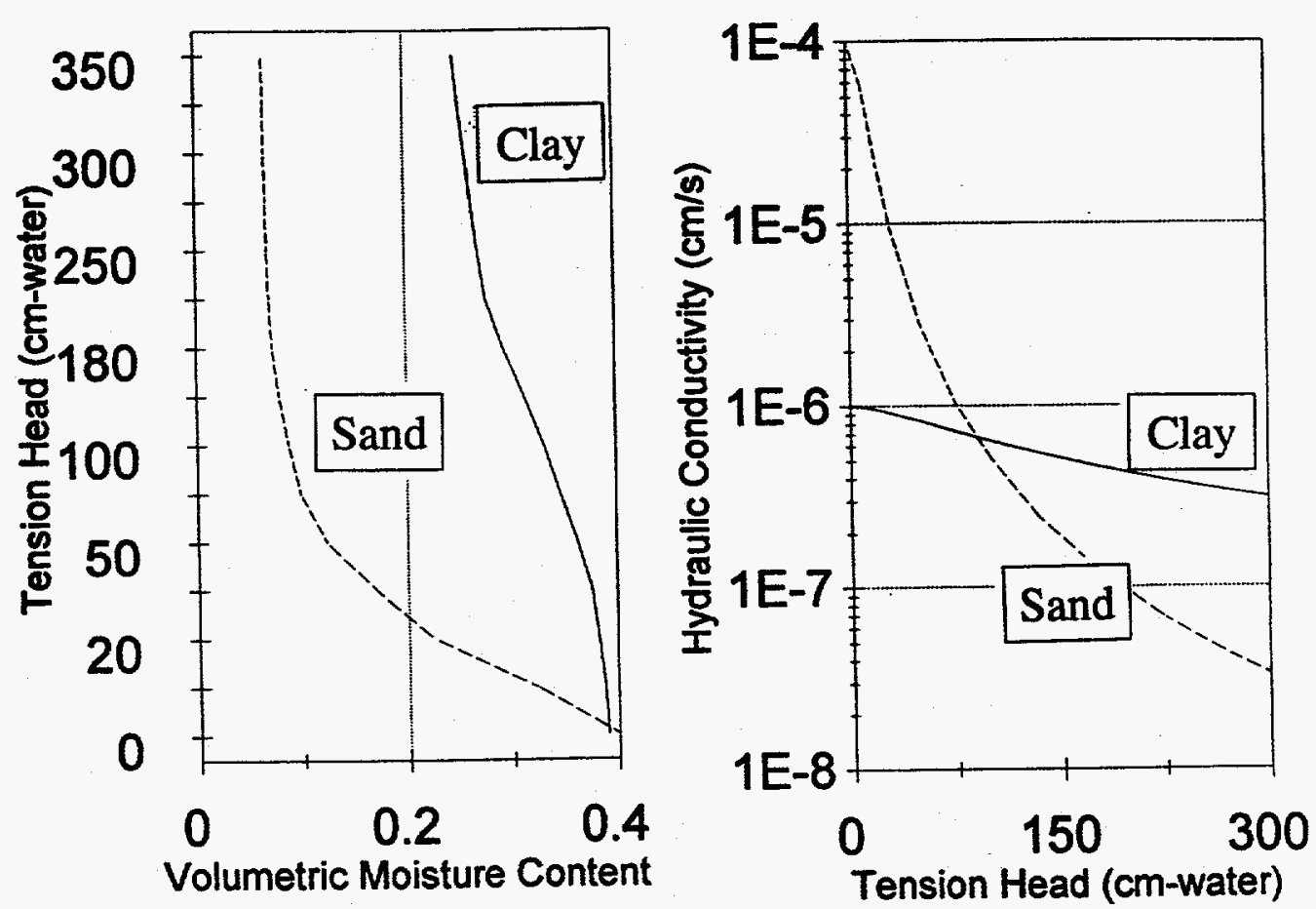

FIGURE 3. Tension Head Versus Volumetric Moisture Content and Hydraulic Conductivity (K) Versus Tension Head 
Although there are 23 septic tank and drainfield sites, 35 sets of calculations were run. ${ }^{1}$ The additional sets of calculations were mainly used to account for uncertainties in the input parameter ranges. The following input parameters were varied in each of these calculation sets: $Q, A, n, K_{s}$, and usually $D_{w r}$. In sampling the parameters, it was assumed that none of the parameters were correlated. Because the ranges and sample distributions assumed for $n$ and $K_{s}$ were the same for all sites, these input parameters will be discussed first.

The values for $n$ were assumed to be uniformly distributed between the values of 0.2 and 0.5. The following information puts this information in perspective. Porosities from repacked samples collected near Technical Area III (near many of the STD sites) at SNL varied from 0.23 to 0.38 (Daniel B. Stephens \& Associates, Inc., 1990 a,b; McTigue and Stein, 1990). Freeze and Cherry (1979) indicate that silt has porosities ranging from 0.35 to 0.50 , sand has porosities ranging from 0.25 to 0.50 , and gravel has porosities ranging from 0.25 to 0.40 . The unsaturated zone underlying most of the sites is generally described as being "unconsolidated and semi-consolidated sands, gravel, silts, and clays" (SNL, 1994). The effective porosity subject to flowing water is probably somewhat less than the total porosity values described above. Thus, the range of porosity values used to calculate absolute travel times to the water table may have resulted in shorter travel times. However, because the calculations are mostly to be used as a relative measure of travel time, we thought that the range of values used was reasonable.
The values for $K_{\mathrm{s}}$ were estimated to be lognormally distributed, with $1.16 \times 10^{-2}$ $\mathrm{ft} /$ day $\left(4 \times 10^{-6} \mathrm{~cm} / \mathrm{s}\right)$ being the .001 quantile value and $10.77 \mathrm{ft} /$ day $\left(4 \times 10^{-3} \mathrm{~cm} / \mathrm{s}\right)$ being the .999 quantile value. These quantile values were based on the measured saturated hydraulic conductivity of repacked soils at the Chemical Waste Landfill and other SNL locations (Daniel B. Stephens \& Associates, Inc., 1990a,b; McTigue and Stein, 1990). Statistical analysis of all the data from these sources confirmed that the data were lognormally distributed. Figure 4 shows the results of the Lilliefors statistical test for normalcy (the lognormal of the saturated hydraulic conductivity is plotted).

The values for the remainder of the parameters $\left(Q, A\right.$, and $\left.D_{w}\right)$ were specific to a particular seepage pit/drainfield site. However, the values for $Q$ and $A$ were both actually the product of two values, one of which was usually not site specific. $Q$ was usually the product of the number of people using the site and the assumed water usage rate per person. Generally, the water usage rate was not site specific and was assumed to be uniformly distributed between 10 and $100 \mathrm{gal} /$ day. The upper end value of 100 $\mathrm{gal} /$ day would allow 10 five-gal toilet flushes and a 50-gal shower per day. Otis et al. (1980) indicate that the average daily wastewater flow from a typical residential dwelling is $45 \mathrm{gal} / \mathrm{day}$, and the maximum is typically no larger than $75 \mathrm{gal} /$ day. These same authors indicate that the typical wastewater flow from an industrial building (excluding industry and cafeteria) ranges from 7.9 to $17.2 \mathrm{gal} / \mathrm{day}$. Thus, the rates we have chosen are rather conservative and

${ }^{1}$ Site 146 was not included in the calculations because there were no available estimates for the discharge rate to the septic system. This site is expected to have one of the lowest discharge rates of all the STD sites. 


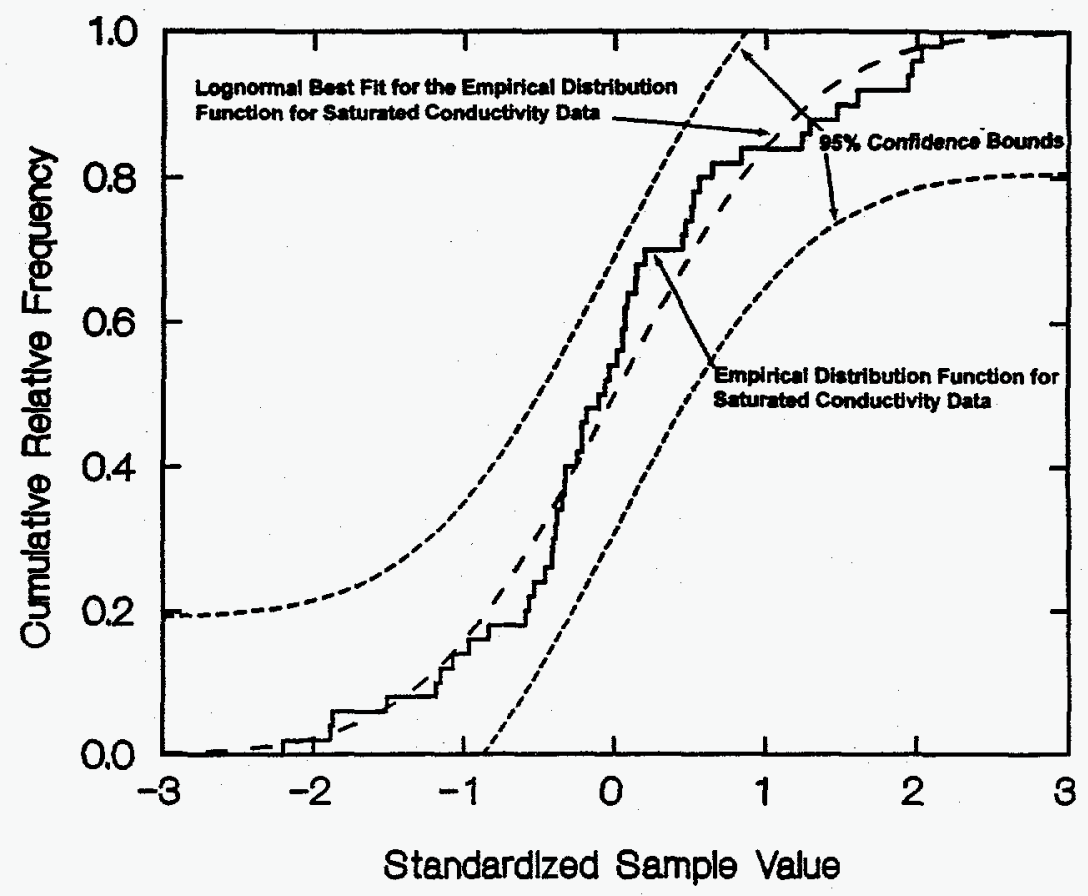

FIGURE 4. Results of Lilliefors Statistical Test for Normalcy (Iman and Conover, 1983) with 95\% Confidence Bounds Displayed

include employee usage plus some industrial usage.

Table 2 lists the values that were used for each site for the number of people and the water usage rate. In some cases, the number of people listed in the table includes fulltime and occasional people. This description is usually associated with sites that had a constant base level of people, the full-time people, and an influx of people, the occasional people, when there was testing at the site. At these sites, it was assumed that $80 \%$ of the time, the number of people at the site was at the base level and the remainder of the time the number of people at the site varied uniformly from the base level to the sum of the base level and influx of people. Figure 5 is an example of the sample distribution used when there were full-time and occasional people at the same site. At sites where only full-time people are specified (see Table 2), a uniform sample was taken over the possible range of full-time people. Figure 6 graphically displays the minimum, maximum, and the arithmetic mean of the water usage rate (the product of the number of people and the water usage rate per person) for all the calculations. The water usage rates are ordered by site geometry. Only two drainfield sites (sites 145 and 147) had significantly higher water usage rates than the seepage pit sites. The site numbers on the $\mathrm{x}$-axis include a designation of $\mathrm{DF}$ for drainfield, DF + SP for drainfield and seepage pit, and SP for seepage pit.

Four sites were assigned water usage rates that differed from the norm of 10 to 100 gal/day/person: sites $49,139,160$, and 154. Site 49 did not have toilet facilities and bottled water was used for drinking. Nonpotable water was trucked in and 
TABLE 2. Description of Site-Specific Input Parameters

\begin{tabular}{|c|c|c|c|c|}
\hline Site & Number of & Water Uange Rinte & Depth to Water & \\
\hline Number & People & (gal/day/person) & Table (t) & Ceomotry Deceription \\
\hline 49 & I tull time, occesionally up to 10 & 10 & 50 & Dpan drain - modeled se eapere pit 2 ft dia \\
\hline 109 & 12 full time & 10 to 100 & 400 to 500 & 2 ecepage plts, ea 5 il die $\times 5$ it deep \\
\hline 116 & 1 tull time, occasionally up to 6 & 10 to 100 & 52 & 4 eecpage plts, ces 5 it dia $\times 9$ if doep \\
\hline 137 & 6 to 8 full time & 10 to 100 & 400 to 500 & $1080 \mathrm{ft}$ draintiold \\
\hline 138 & 12 full time & 10 to 100 & 400 to 500 & $240 \mathrm{ft}$ drainfield \\
\hline $139 a$ & 1 full time & 10 & 50 10 150 & 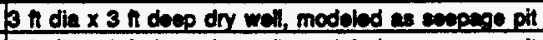 \\
\hline $139 b$ & 1 full time & 10 & 300 to 400 & 3 it die $x 3$ if deep dry weil, modeled as seepere oft \\
\hline $140 \mathrm{a}$ & 1 full time, occasionally up to 5 & 10 to 100 & 50 to 150 & 6 if dia $\times 61 / 2$ ft deco cecosege plt \\
\hline $140 b$ & 1 full tima, occasionally up io 5 & 10 to 100 & 300 to 400 & 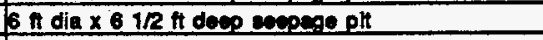 \\
\hline $141 a^{\circ}$ & 1 full time & 10 to 100 & 50 to 150 & 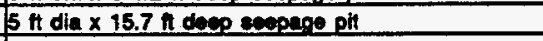 \\
\hline $141 c^{\circ}$ & 1 full time & 10 to 100 & 300 10 400 & 5 ft dia $x 15.7$ it deep ecepene pit \\
\hline $142 a$ & 3 full time & 10 to 100 & 50 to 150 & 4 it dia $\times 5$ it deep cecerepe pit \\
\hline $142 b$ & 3 full time & 10 to 100 & 100 to 200 & 4 it die $\times 5$ it deap ecepere plt \\
\hline 1438 & 5 full time & 10 to 100 & 50 to 150 & 800 t drainfield \\
\hline $143 \mathrm{~b}$ & 5 full time & 10 to 100 & 100 to 200 & 300 in drainfield \\
\hline 1448 & 0 to 5 full time & 10 to 100 & $5010 \quad 150$ & 300 it drainfield \\
\hline $144 b$ & 0 to 5 full time & 10 to 100 & 200 to 300 & 300 it drainfield \\
\hline $145 a$ & 30 to 50 full time & 10 to 100 & $5010 \quad 150$ & 75 it drainfield \\
\hline $145 b$ & 30 10 50 tull time & 10 to 100 & 200 to 300 & $75 \mathrm{ft}$ drainfield \\
\hline $147 a$ & 10 full time, occesionally up to 30 & 10 to 100 & 50 to 150 & 130 it dranfield \\
\hline 1476 & 10 full time, occasionally up to 30 & 10 to 100 & 50 to 150 & 450 drainfield \\
\hline 148 & 2 full time, occasionally up to 5 & 10 to 100 & 400 to 500 & If dia $\times 10$ it daep eacpage plt*" \\
\hline $149 a$ & 4 full time, occesionally up to 8 & 1010100 & 300 to 400 & 4 it dla $x 4$ fit deep ceopage ph \\
\hline $149 b$ & 4 full time, occasionally up to 8 & 10 to 100 & 50 to 150 & $4 \mathrm{ft}$ dia $\times 4$ fi deop seepege pit \\
\hline $150 \mathrm{~B}$ & 2 full time occasionally up to 4 & 10 to 100 & 150 to 200 & 2 coopage pits, ea 8 it dia $\times 9 \mathrm{H}$ doep \\
\hline $150 b$ & 2 full time, occasionally up to 4 & 1010100 & 50 10 150 & 2 soepage pits, ea 9 it dia $\times 9$ it doep \\
\hline 151 & 4 full time & 10 to 100 & 300 to 400 & $6.5 \mathrm{ft}$ dia $\times 7.3 \mathrm{H}$ deep eeepage $\mathrm{pit}$ \\
\hline 152 & 9 full time & 10 to 100 & 400 to 500 & $40 \mathrm{n}$ drainfield 85 in die $\times 5$ i deep secosege pit \\
\hline $153 a$ & 15 full time & 10 to 100 & 400 to 500 & 200 ft drainfield 85 ft dia $\times 5$ it deep ceepage pit \\
\hline $153 b$ & 15 full time & 10 to 100 & 400 to 500 & 5 it dia $\times 5$ ft deep secoene plt \\
\hline $154 a$ & 4 full time & 10 to 100 & 50 to 150 & 5 th dia $\times 5$ ft deep seepege ph \\
\hline $154 b$ & 4 full time & 10 to 100 & 200 to 300 & $5 \mathrm{ft}$ dia $\times 5 \mathrm{ft}$ deep seepege pit \\
\hline $154 \mathrm{c}$ & 0 to 1 full time & 300 & 200 to 300 & 2 seopage pits, es 5 n dia $\times 20$ n deep \\
\hline 160 & I full time & 10 to 50 & 50 & 4 if dia $\times 15.7$ if deep scepage pit \\
\hline 161 & h occasional (modelec w/ 0 to 1 full time) & 10 to 100 & 400 to 500 & $620 \mathrm{n}$ drainfield \\
\hline
\end{tabular}

The results from 1416 are not included as part of this report

* Aithough the seepage pit for site 148 is only 4 feet deep, the seopage pit isself starts 6 feet bolow ground lovel. 


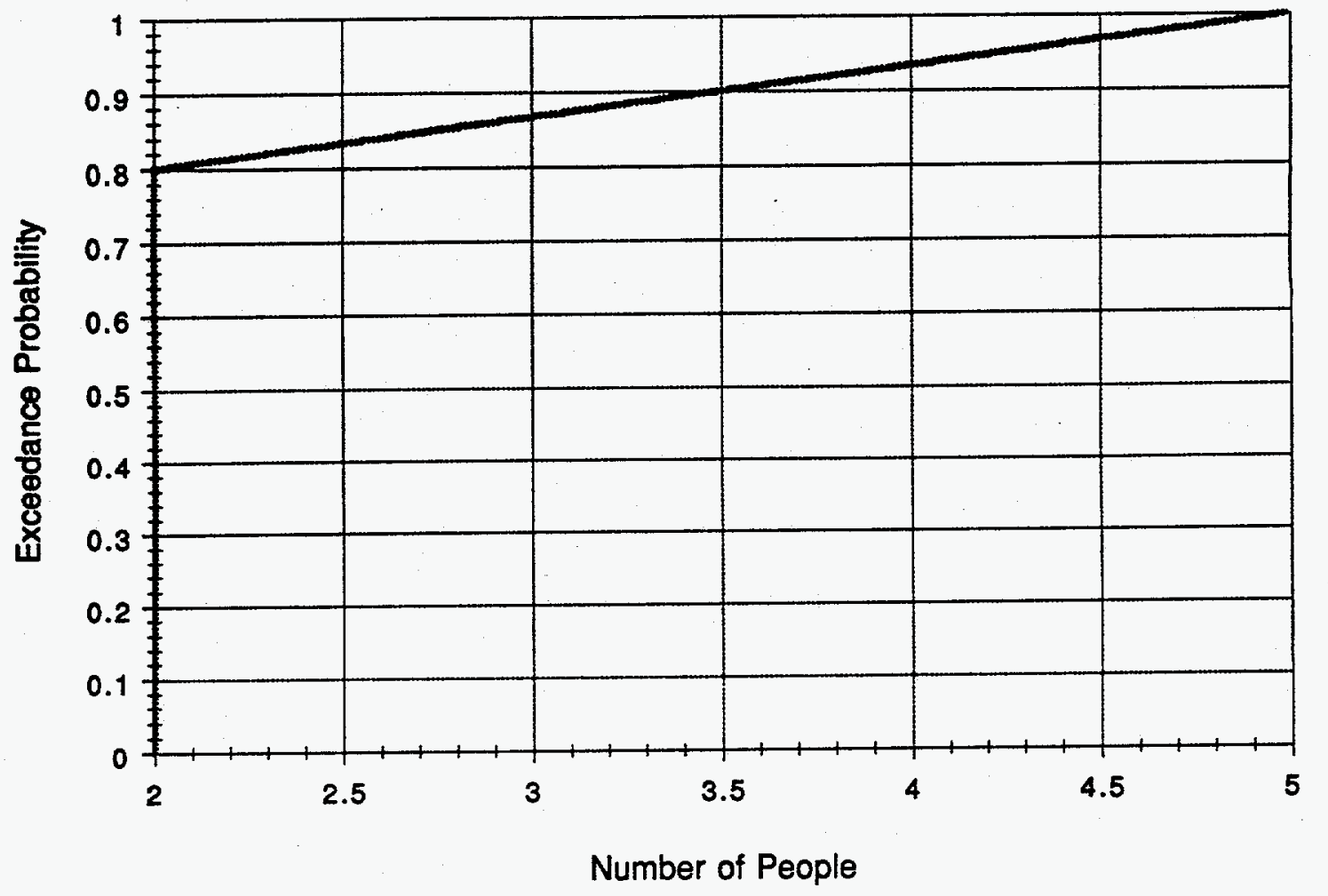

FIGURE 5. Example Sample Distribution for Number of People when There Are Full-Time and Occasional People (site 148 is given as the example)

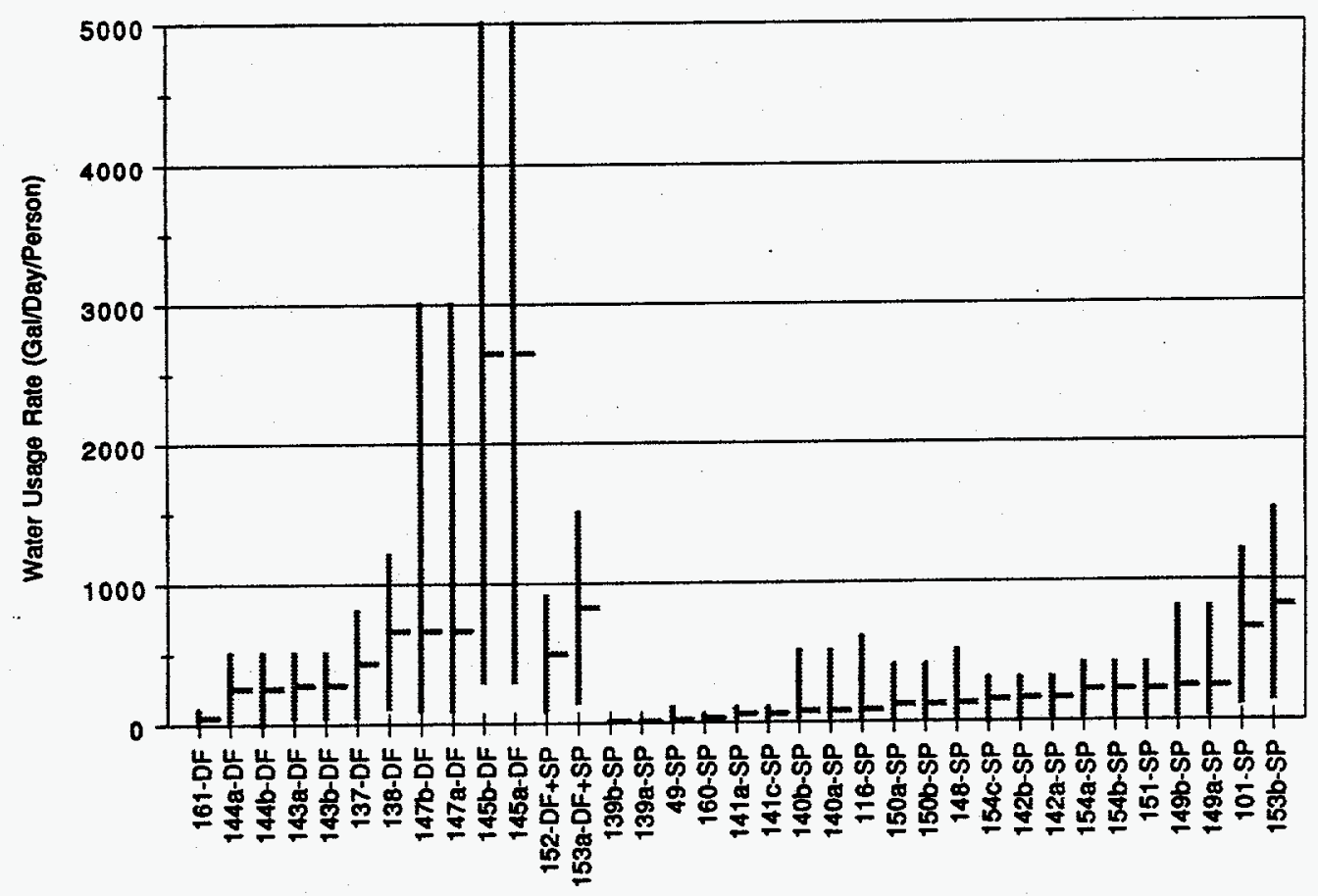

FIGURE 6. Minimum, Maximum, and Arithmetic Mean of Water Usage Rate for All Calculations Completed (ordered by geometry and mean water usage rate) 
stored in a 1000-gal water supply tank. Although it is unknown how often the water supply tank was replenished, it was assumed that the water usage rate for this site was 10 gal/day/person. Site 139 had no sinks or toilet facilities in the building and no water supply. Again, the water usage rate for this site was assumed to be $10 \mathrm{gal} /$ day/person. Site 160 had no toilets, and the building is not connected to any permanent water supply. The site had a central wash-down trough and a sink for hand washing; water for washing was transported by truck to a holding tank. This description led us to believe that more water was used here than at sites 49 and 139. Therefore, the water usage rate for this site was chosen to range between 10 to $50 \mathrm{gal} /$ day/person. Documentation for site 154 indicated that up to 300 $\mathrm{gal} / \mathrm{day}$ of water may have been comtaminated in hosing down machines and the building floor. The discharge area for this water was separate from that for the sewage system. For this reason, we added a third calculation in which the water usage varied uniformly between zero and 300 gal/day. Two other sets of calculations were completed for site 154 . These calculations were based solely upon the number of people in the building and a water usage rate of 10 to $100 \mathrm{gal} /$ day/person.

Site 161 was handled differently from other sites that had occasional employees because there were no full-time employees and only an occasional employee. To avoid the computational problems associated with zero employees, the number of people at this site was sampled uniformly over the range 0 to 1. This variation in approach means that the actual travel times for site 161 should probably be slightly greater than those calculated.

The bounds chosen for the water usage rate may be a little high because the calculations use a seven-day water usage rate rather than a five-day workweek water usage rate. This information is poorly characterized for these sites. It is not known how the number of people actually varied over time, and no one has characterized the water usage rates at these sites.

In determining the area, $A$, the engineered horizontal drainage area was considered along with another parameter called the spread constant, $S_{c}$. For all the sites, the spread constant was assumed to vary uniformly between 1 and 3 feet. The spread constant accounts for lateral spreading of infiltrating water beyond the bounds of the engineered drainage area. The spread constant was added to the diameter of the seepage pits and drywells and was added to the constant 2-ft width of the drainfield trenches. Figure 7 illustrates how the spread constant expands the original geometry of a seepage pit. The spread constants were based on recent research by McCord (1991) related to anisotropy for unsaturated flow. This research suggests that the lateral spreading can be quite large; thus, the spread constant may be significantly larger than one.

The dimensions of the engineered features used in the calculations are summarized in Table 2. In three cases (sites 147,153 , and 154), an additional set of calculations was completed for each site because of variations in the engineered geometry. Site 147 had two drainfields associated with it. One set of calculations was completed with the original drainfield that serviced the building, a drainfield of 130 linear feet. Because this drainfield was later abandoned, a second calculation was completed with its replacement, a drainfield of $\mathbf{4 5 0}$ linear feet. For site 153 , the geometry changed from only a seepage pit in 1969 to a drainfield and seepage pit in 1978 . For site 154 , there were two separate drainage systems. Two seepage pits existed for "industrial" use and 


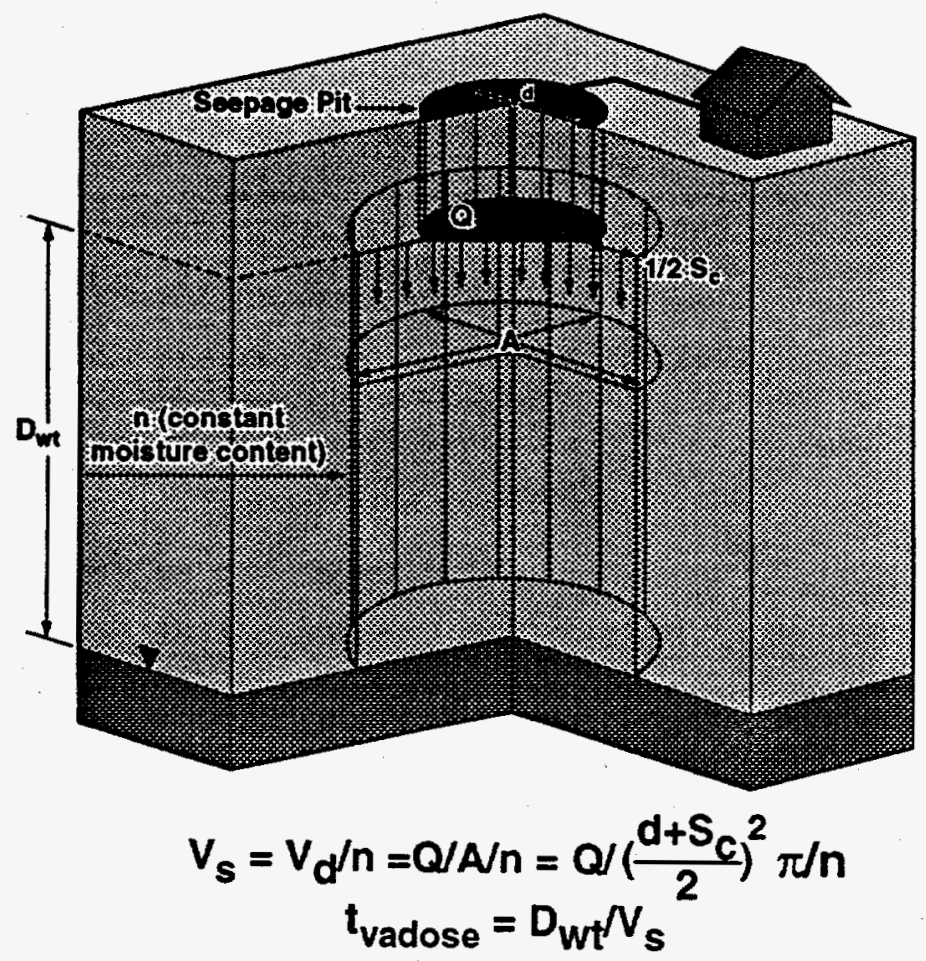

FIGURE 7. Seepage Pit Diagram and Equation for Travel Time to the Water Table

a separate single seepage pit for sanitary wastes.

The information about the engineered geometry of the sites is the best characterized of the input data; however, the spread factor could be different from that used in the calculations. We expect that this uncertainty will not be as large an influence on the travel time as some of the uncertainties in the other input parameters.

The last input parameter is the depth to the water table. It was assumed to be uniformly distributed. In many cases, two sets of calculations were run for each site because of uncertainties regarding the depth to the water table. The depth values used in the calculations are also summarized in Table 2. One set of calculations used the range that was included in the original description of each site in the RCRA Facility Investigation (RFI) for the Septic Tanks and Drainfields activity (SNL, 1993). The depth range in the second set of calculations is based on a map of the potentiometric surface of the SNL/KAFB area included in the report for the Site-Wide Hydrogeologic Characterization Project for the 1992 calendar year (Crowson et al., 1993). STD sites in this category include sites 139 through 145,149 , 150 , and 154. For the sites that had drainfields, the effluent was assumed to travel from the surface to the groundwater table. Because of the significant depth of the seepage pits, the effluent was assumed to start its path to the water table from the bottom of the seepage pit. The seepage pit geometry is illustrated in Figure 7. Figure 8 graphically presents the minimum, maximum, and arithmetic mean of the depth to the water table. It is ordered by system geometry. This figure indicates that both seepage pits and drainfields include a wide range of depths. 


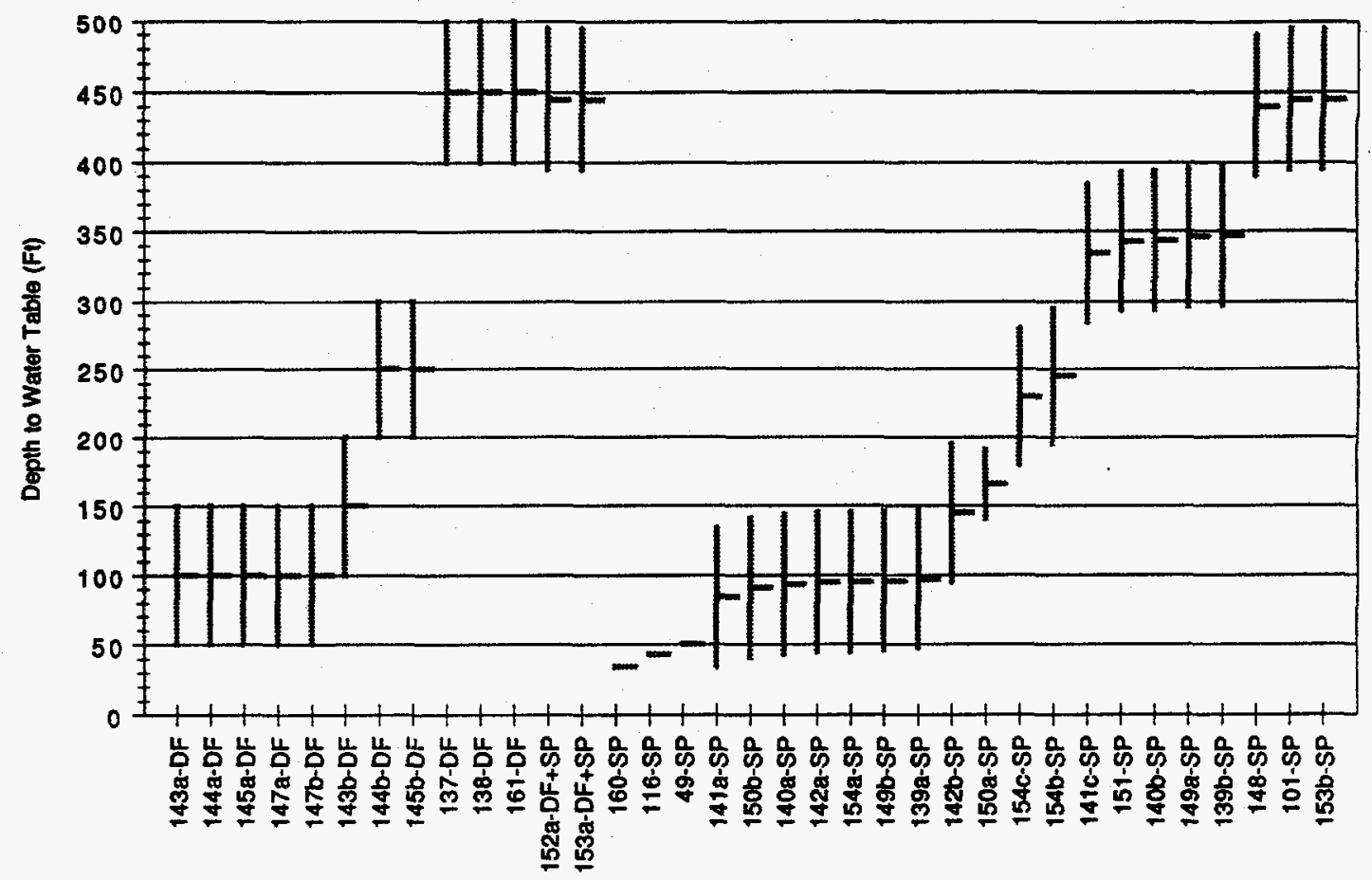

FIGURE 8. Minimum, Maximum, and Arithmetic Mean of Depth to the Water Table for All Calculations Completed (ordered by geometry and depth to the water table)

\section{RESULTS}

Tables 3 and 4 list the minimum, maximum, and arithmetic mean for the travel times from the first and second pass of the travel time calculations. As discussed above, the first pass assumes that water moves to the water table at the rate that it is discharged through the seepage pit or drainfield area. The results of this pass are shown in Figures 9,11 and 13. In the second pass, the seepage velocity was potentially limited by the saturated hydraulic conductivity value that was sampled. (Although the hydraulic conductivity was only limited by the saturated hydraulic conductivity if the calculated discharge exceeded the saturated hydraulic conductivity, in the remaining figures and future discussion about the calculations potentially limited by saturated hydraulic conductivity, the adverb "potentially" is dropped, and the calculations are referred to as "limited" by saturated hydraulic conductivity.) The second-pass results are shown in Figures 10,12 and 14. Figures 9 and 10 are ordered by the site number, Figures 11 and 12 are ordered by the mean travel time, and Figures 13 and 14 are ordered by geometry and mean travel time. In Figure 12, where the velocities are limited by the saturated hydraulic conductivity, most of the mean travel times are between 1.0 and 10.0 year.

In the other case where the maximum flux was not limited by the saturated hydraulic conductivity (Figure 11), about half the travel times range between 0.1 and 1.0 year. Limiting the velocities by the saturated hydraulic conductivities smoothed the differences in the mean travel times for the sites but increased the range of the minimum to maximum values for a given site. This is 
TABLE 3. Travel Time to the Groundwater Table when Velocity IS NOT Limited by Saturated Hydraulic Conductivity

\begin{tabular}{|c|c|c|c|}
\hline Site & Minimum Travel & Maximum Travel & Mean Travel \\
\hline Number & Time (Yr) & Time $\left(Y_{r}\right)$ & Time $(Y r)$ \\
\hline 49 & 0.02 & 0.94 & 0.39 \\
\hline 101 & 0.09 & 2.81 & 0.53 \\
\hline 116 & 0.14 & 4.13 & 0.95 \\
\hline 137 & 13.22 & 383.03 & 66.35 \\
\hline 138 & 1.29 & 38.92 & 6.55 \\
\hline $139 a$ & 0.27 & 3.96 & 1.38 \\
\hline $139 b$ & 1.69 & 10.98 & 4.95 \\
\hline $140 a$ & 0.04 & 5.60 & 0.77 \\
\hline $140 \mathrm{~b}$ & 0.19 & 15.28 & 2.79 \\
\hline $141 \mathrm{a}$ & 0.07 & 4.34 & 0.61 \\
\hline $141 b$ & 0.02 & 2.10 & 0.30 \\
\hline $141 \mathrm{c}$ & 0.45 & 14.23 & 2.35 \\
\hline $142 a$ & 0.02 & 1.07 & 0.16 \\
\hline $142 b$ & 0.04 & 1.47 & 0.25 \\
\hline $143 a$ & 0.58 & 27.10 & 4.36 \\
\hline $143 b$ & 1.03 & 43.78 & 6.66 \\
\hline $144 a$ & 0.67 & $2,581.72$ & 32.72 \\
\hline $144 b$ & 2.03 & $34,505.60$ & 105.93 \\
\hline $145 a$ & 0.02 & 1.04 & 0.14 \\
\hline $145 b$ & 0.06 & 2.18 & 0.35 \\
\hline $147 a$ & 0.04 & 5.61 & 0.88 \\
\hline $147 \mathrm{~b}$ & 0.14 & 19.41 & 3.04 \\
\hline 148 & 0.11 & 6.30 & 1.06 \\
\hline $149 a$ & 0.06 & 2.31 & 0.42 \\
\hline $149 b$ & 0.01 & 0.81 & 0.12 \\
\hline $150 a$ & 0.38 & 14.45 & 2.70 \\
\hline $150 \mathrm{~b}$ & 0.14 & 12.57 & 1.49 \\
\hline 151 & 0.17 & 6.53 & 0.91 \\
\hline 152 & 0.32 & 11.19 & 1.83 \\
\hline $153 a$ & 0.89 & 26.93 & 4.52 \\
\hline $153 b$ & 0.04 & 1.28 & 0.21 \\
\hline $154 a$ & 0.02 & 1.05 & 0.17 \\
\hline $154 b$ & 0.09 & 2.31 & 0.43 \\
\hline $154 \mathrm{c}$ & 0.22 & 414.91 & 3.29 \\
\hline 160 & 0.06 & 1.21 & 0.28 \\
\hline 161 & 47.09 & $644,936.00$ & $2,553.63$ \\
\hline
\end{tabular}


TABLE 4. Range of Calculated Travel Times to the Groundwater Table when Velocity IS Limited by Saturated Hydraulic Conductivity

\begin{tabular}{|c|c|c|c|}
\hline Site & Minimum Travel & Maximum Travel & Mean Travel \\
\hline Number & Time (Yr) & Time $\left(Y_{r}\right)$ & Time (Yr) \\
\hline 49 & 0.02 & 2.99 & 0.47 \\
\hline 101 & 0.18 & 43.68 & 2.30 \\
\hline 116 & 0.06 & 6.96 & 1.09 \\
\hline 137 & 8.71 & 356.53 & 51.46 \\
\hline 138 & 1.31 & 44.13 & 7.02 \\
\hline $139 a$ & 0.28 & 12.06 & 1.47 \\
\hline $139 b$ & 1.81 & 26.63 & 5.23 \\
\hline $140 a$ & 0.05 & 12.13 & 0.94 \\
\hline $140 b$ & 0.24 & 20.89 & 3.38 \\
\hline $141 \mathrm{a}$ & 0.06 & 8.04 & 0.78 \\
\hline $141 c$ & 0.46 & 28.44 & 2.96 \\
\hline $142 a$ & 0.02 & 10.34 & 0.51 \\
\hline $142 b$ & 0.04 & 12.40 & 0.78 \\
\hline $143 a$ & 0.59 & 31.34 & 4.41 \\
\hline $143 b$ & 1.06 & 43.77 & 6.63 \\
\hline $144 a$ & 0.70 & $3,567.43$ & 28.05 \\
\hline $144 b$ & 2.74 & $31,480.00$ & 307.41 \\
\hline $145 a$ & 0.02 & 13.47 & 0.51 \\
\hline $145 b$ & 0.09 & 15.76 & 1.28 \\
\hline $147 a$ & 0.08 & 7.59 & 1.03 \\
\hline $147 b$ & 0.26 & 26.29 & 3.04 \\
\hline 148 & 0.19 & 26.19 & 2.47 \\
\hline $149 a$ & 0.10 & 29.94 & 1.78 \\
\hline $149 b$ & 0.02 & 7.30 & 0.48 \\
\hline $150 a$ & 0.43 & 16.33 & 2.86 \\
\hline $150 b$ & 0.18 & 10.95 & 1.56 \\
\hline 151 & 0.18 & 30.93 & 1.99 \\
\hline 152 & 0.38 & 37.67 & 2.96 \\
\hline $153 a$ & 0.90 & 27.32 & 4.93 \\
\hline $153 \mathrm{~b}$ & 0.10 & 19.08 & 1.75 \\
\hline $154 a$ & 0.02 & 7.25 & 0.50 \\
\hline $154 \mathrm{~b}$ & 0.08 & 26.95 & 1.32 \\
\hline $154 c$ & 0.22 & 414.91 & 3.79 \\
\hline 160 & 0.07 & 2.05 & 0.33 \\
\hline 161 & 48.29 & $138,675.00$ & $1,368.41$ \\
\hline
\end{tabular}




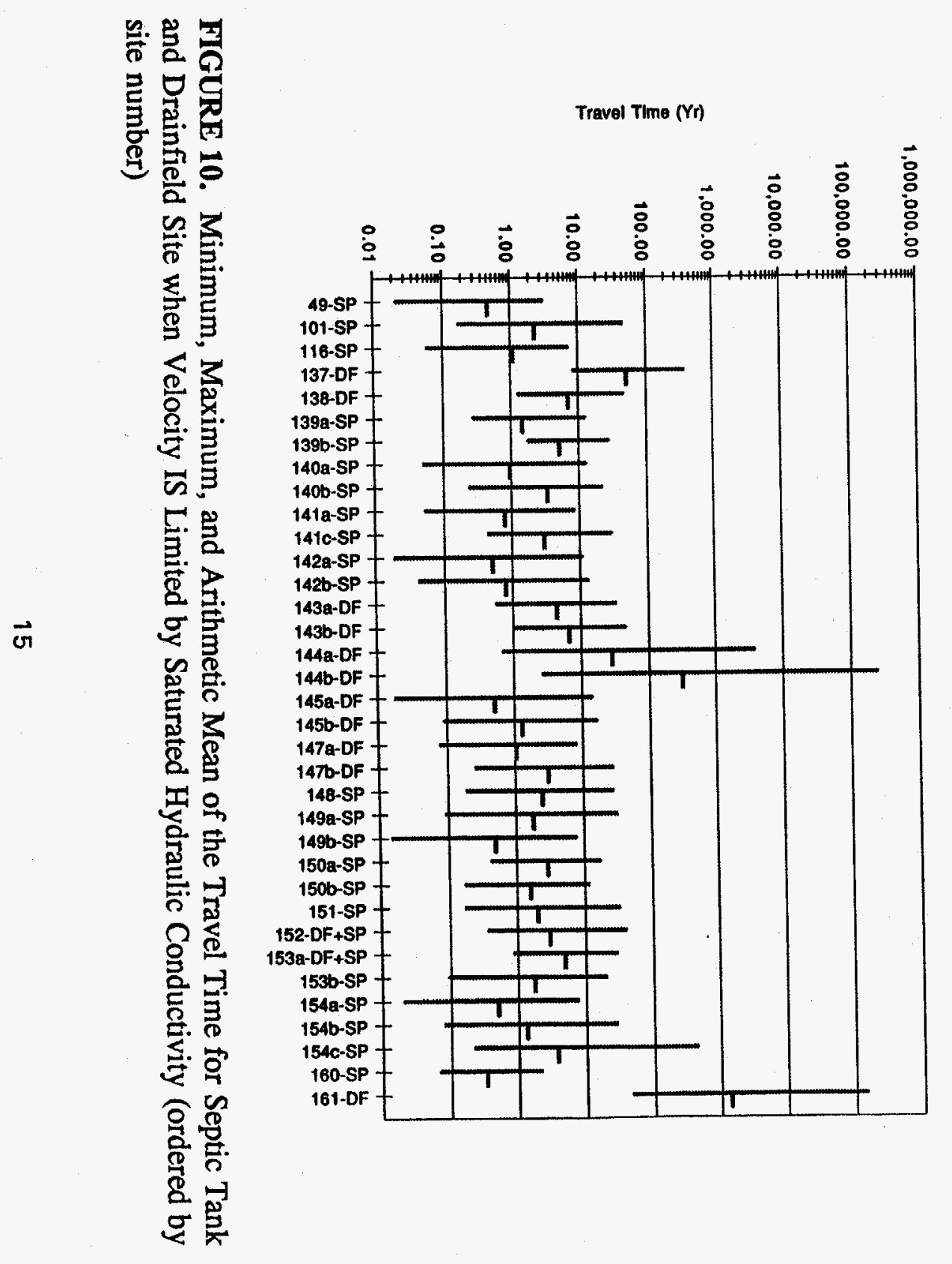

옴릴

응

區㝴

远豆

․․ㄹㄹㅇ

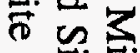

䒠节

క

沓志

के

迥寻

․․․

岂

忌忌

동

总

83

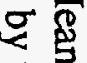

둥요

㐘

雚

붕

¿

要

옥

를

통 옴

ก

을 罾

空官.

总 包

Travel Time (Yr)

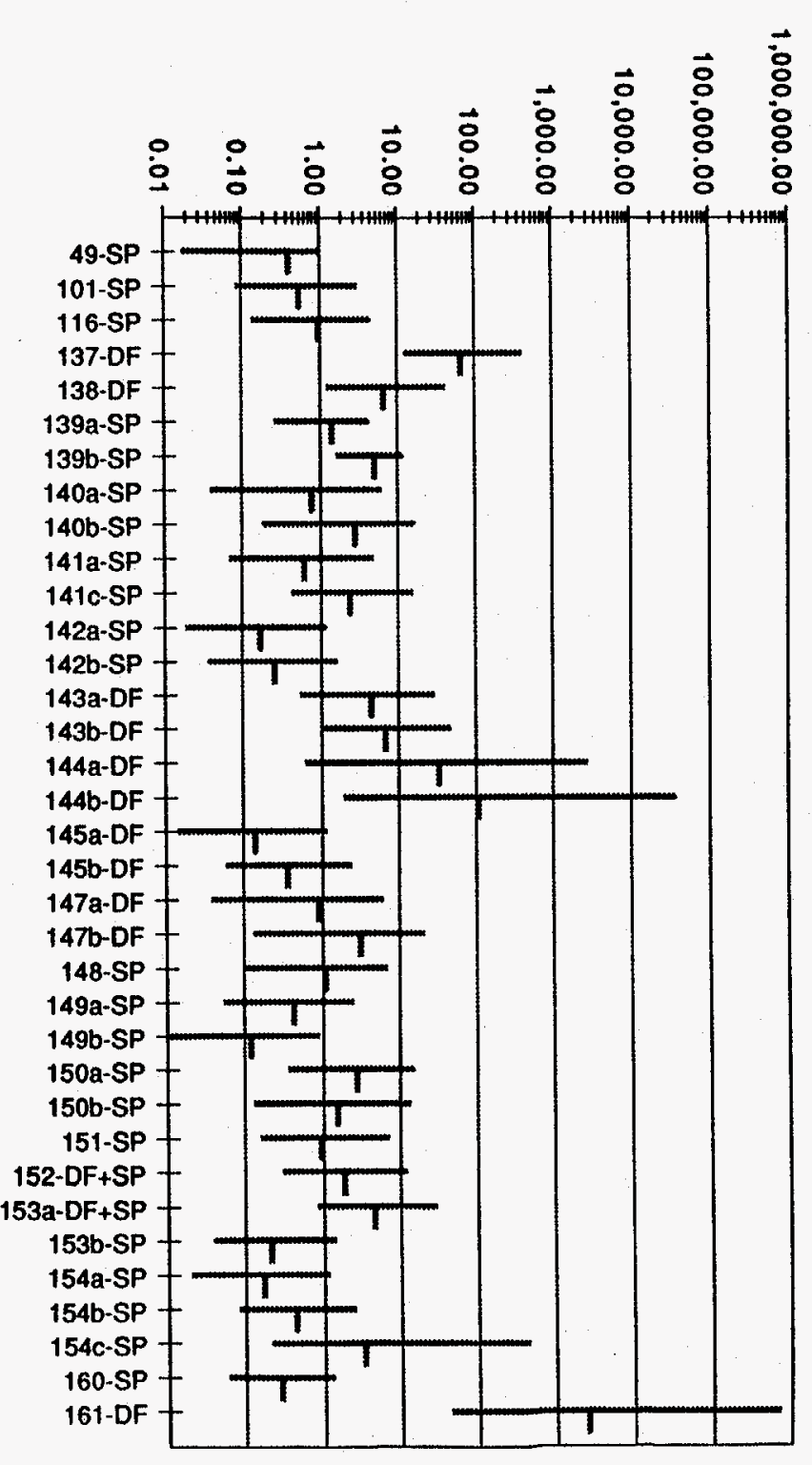




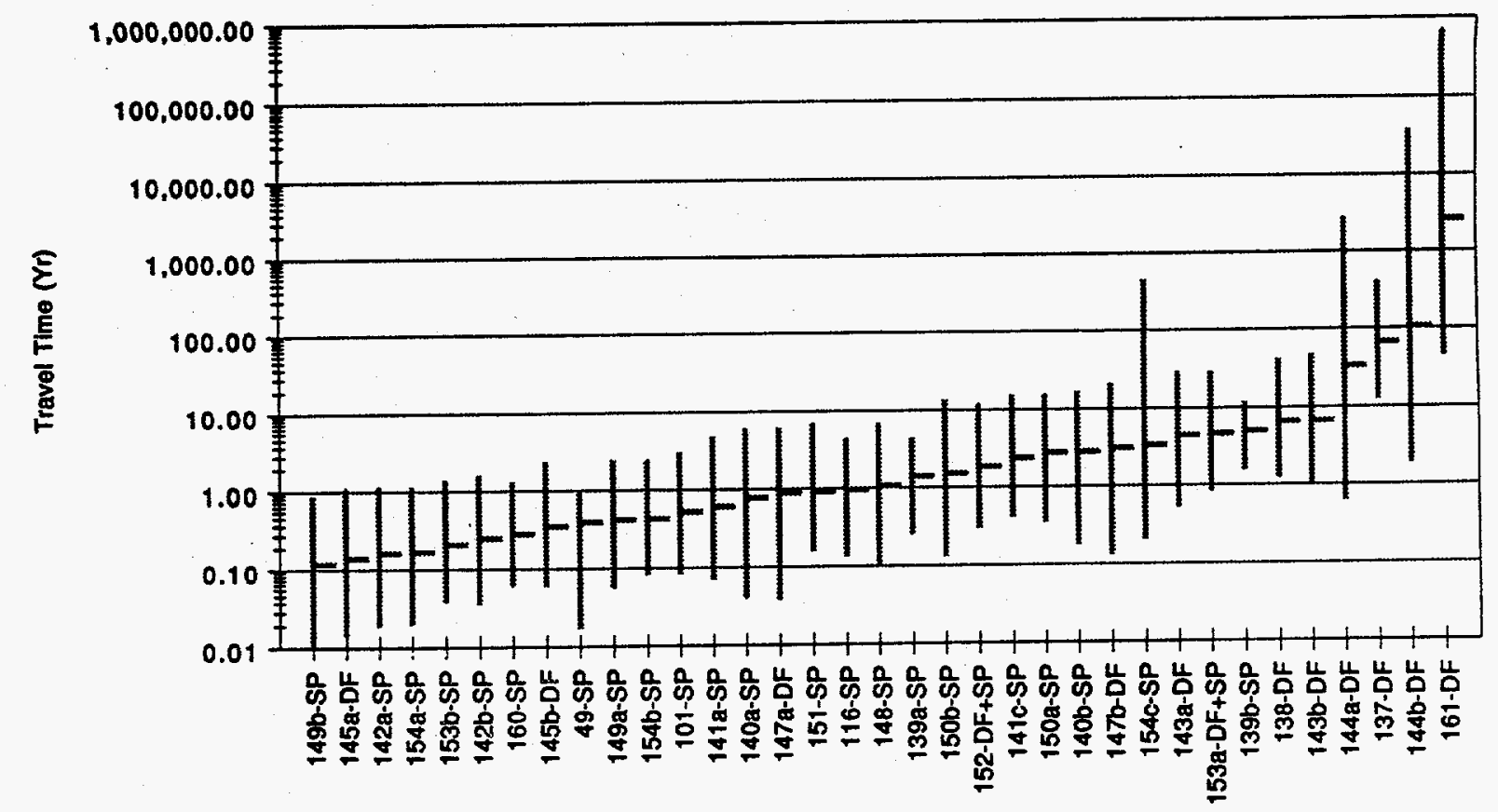

FIGURE 11. Minimum, Maximum, and Arithmetic Mean of the Travel Time for Septic Tank and Drainfield Site when Velocity Is NOT Limited by Saturated Hydraulic Conductivity (ordered by mean travel time)

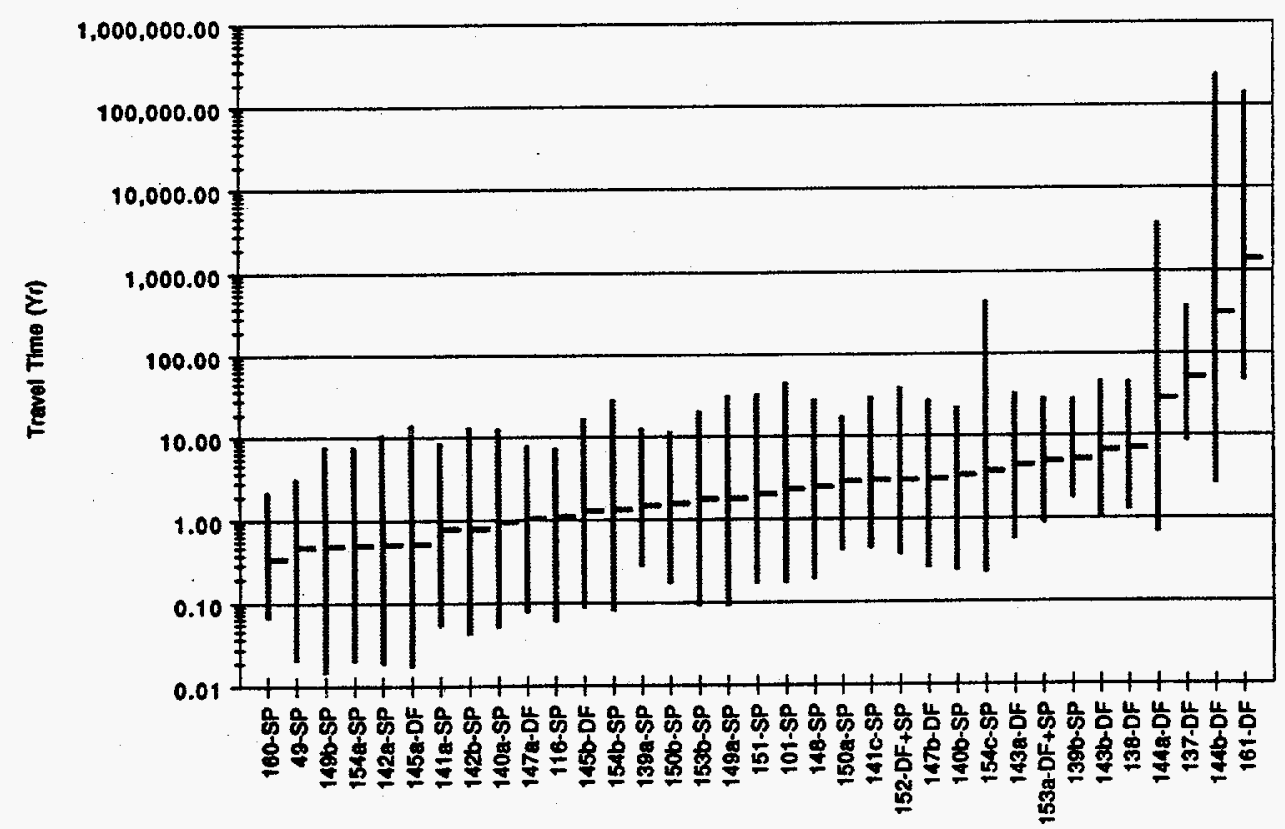

FIGURE 12. Minimum, Maximum, and Arithmetic Mean of the Travel Time for Septic Tank and Drainfield Site when Velocity IS Limited by Saturated Hydraulic Conductivity (ordered by mean travel time) 


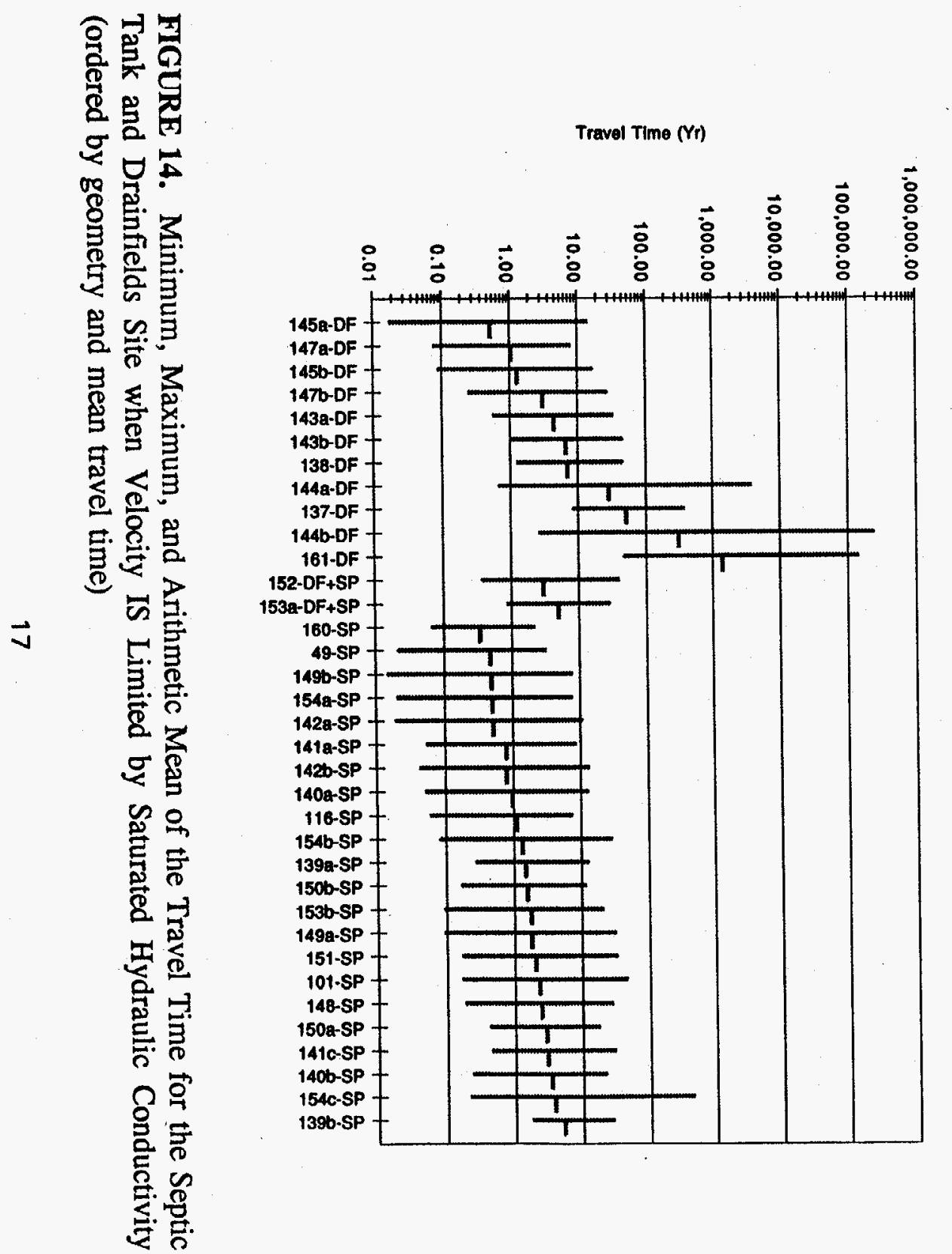

高高园

\&

돈

串

骂 造.

沗定

承

占 $\leftleftarrows$

要

要

ङ

홍 옵

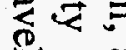

ㅌ. 的莕

寻忌茪

苯. 灵

荧?

g

舟虽

官

可

工市

运붕

范苛

ते

ช

艿

릉

总

影
Travel Time (Yr)

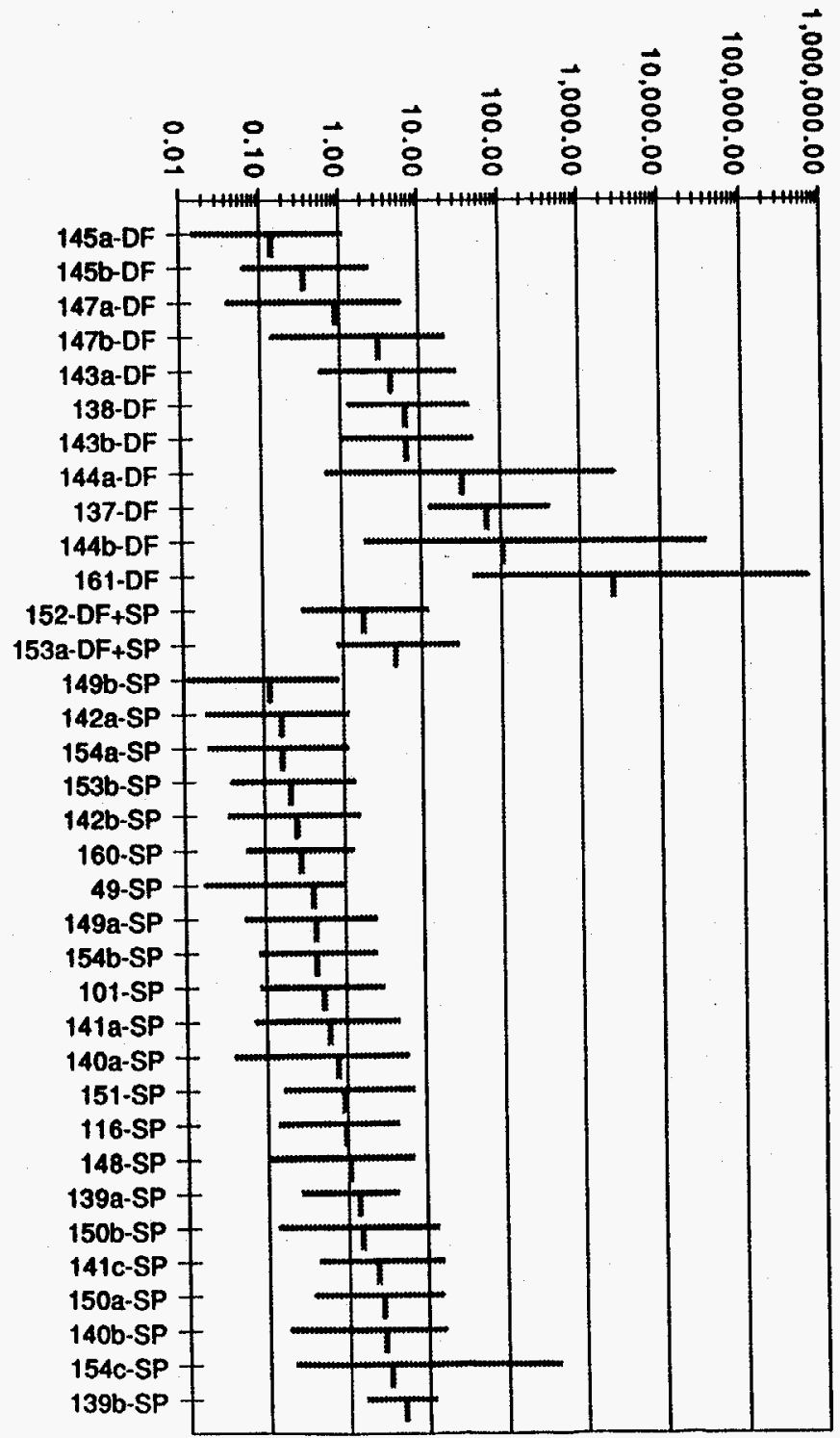


the last that will be discussed of the pass in which the travel times were not limited by the saturated hydraulic conductivity. The results from the pass in which travel times were limited by the saturated hydraulic conductivity are considered to be more realistic and were selected to determine the priority ranking of the sites. These results will be the focus of the remainder of this section.

To use the travel time results to rank the sites, the multiple sets of calculations for a given site had to be combined. The arithmetic means of all the calculations for a given site were averaged; the minimum of the minimal values and the maximum of the maximal values of all the calculations for a given site were preserved. As in the previous travel time plots, the resulting combined information is displayed in three figures, one ordered by mean travel time (Figure 15 ), one by geometry (Figure 16), and one by site number (Figure 17). The $\mathrm{x}$-axis of each of these plots also indicates the priority established for each site on the basis of travel time. The priority was determined in the following manner. The minimum values were assigned a number from 1 to 4 . Each number corresponded to a major subdivision on a logarithmic scale (i.e., a 1 corresponded to a minimum value in the range of 0.01 to 0.10 , a 2 corresponded to a minimum value in the range of 0.10 to 1.00 , etc.). The maximum values were assigned a number in a similar manner. A 1 corresponded to a maximum value in the range of 1.00 to 10.00 , a 2 to a maximum value in the range to 10.00 to 100.00 , etc. Because there was not as large a variation in the mean travel times, the numbers assigned to the mean values were based on one-half a major subdivision on a logarithmic scale (i.e., a 1 corresponded to values from 0.5 to 1.0 , a 2 to values from 1.0 to 5.0 , etc.). The values assigned to the mean travel time were multiplied by two and added to the values assigned to the minimum and maximum values to determine the final ranking of the sites. This sum was then used to group the sites into five different priority groups. The priorities assigned to the sites are shown on the $\mathrm{X}$-axis of Figures 15 through 17. For example, the designation $140-3$, SP indicates that site 140 is a seepage site with a priority of 3 . For the most part, the priorities assigned are in the order of increasing mean travel time. However, some of the priority 2,3 , and 4 sites do not follow this pattern.

The differences in travel time between the first and the fifth priorities are significant enough to indicate a potential for differences in risk to human health and the environment. However, the travel times (arithmetic mean, minimum, and maximum) for the remainder of the sites are so close in value that someone else could easily arrive at a different prioritization scheme if given the same data. For these sites, the present prioritization scheme only serves to divide the sites into more manageable subgroups. With more information or consideration of the health hazards of the contaminants of concern, the prioritization of these sites could easily change.

\section{Comparison with Other Results}

The travel times computed using Equation 1 are, for most of the sites, so short that a second, more rigorous study was undertaken for comparison purposes. We chose to model site 160 because of its short travel times, constant groundwater depth, and well-defined geometry. Goodrich (1994) calculated the travel time of a nonsorbing contaminant from the bottom of the seepage pit to the water table in two dimensions using VS2DT, a two-dimensional finitedifference code that solves Richard's equation for flow and the convection/dispersion 


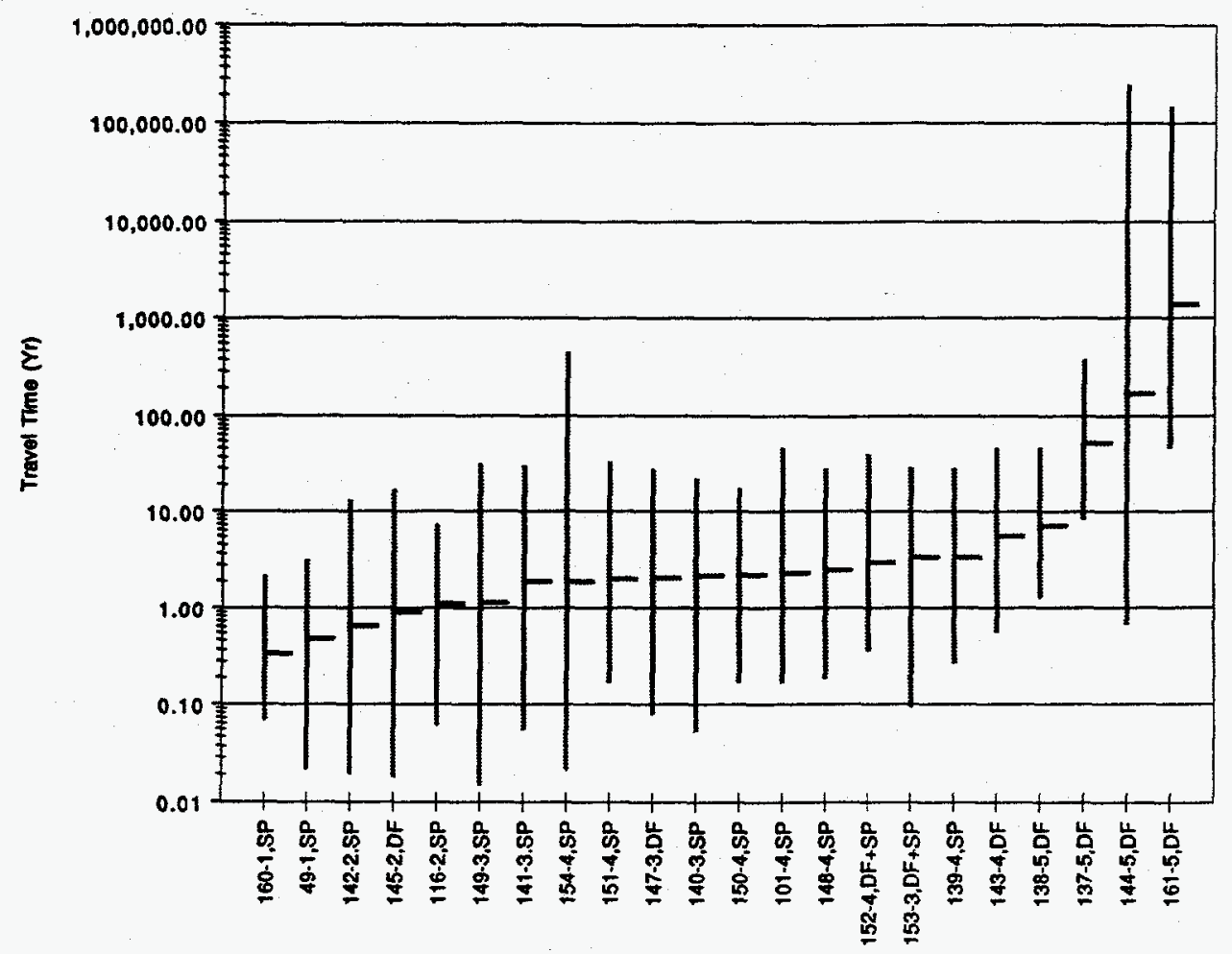

FIGURE 15. Ranking and the Minimum, Maximum, and Arithmetic Mean of the Travel Time for Seepage Pit and Drainfield Sites (ordered by mean travel time)

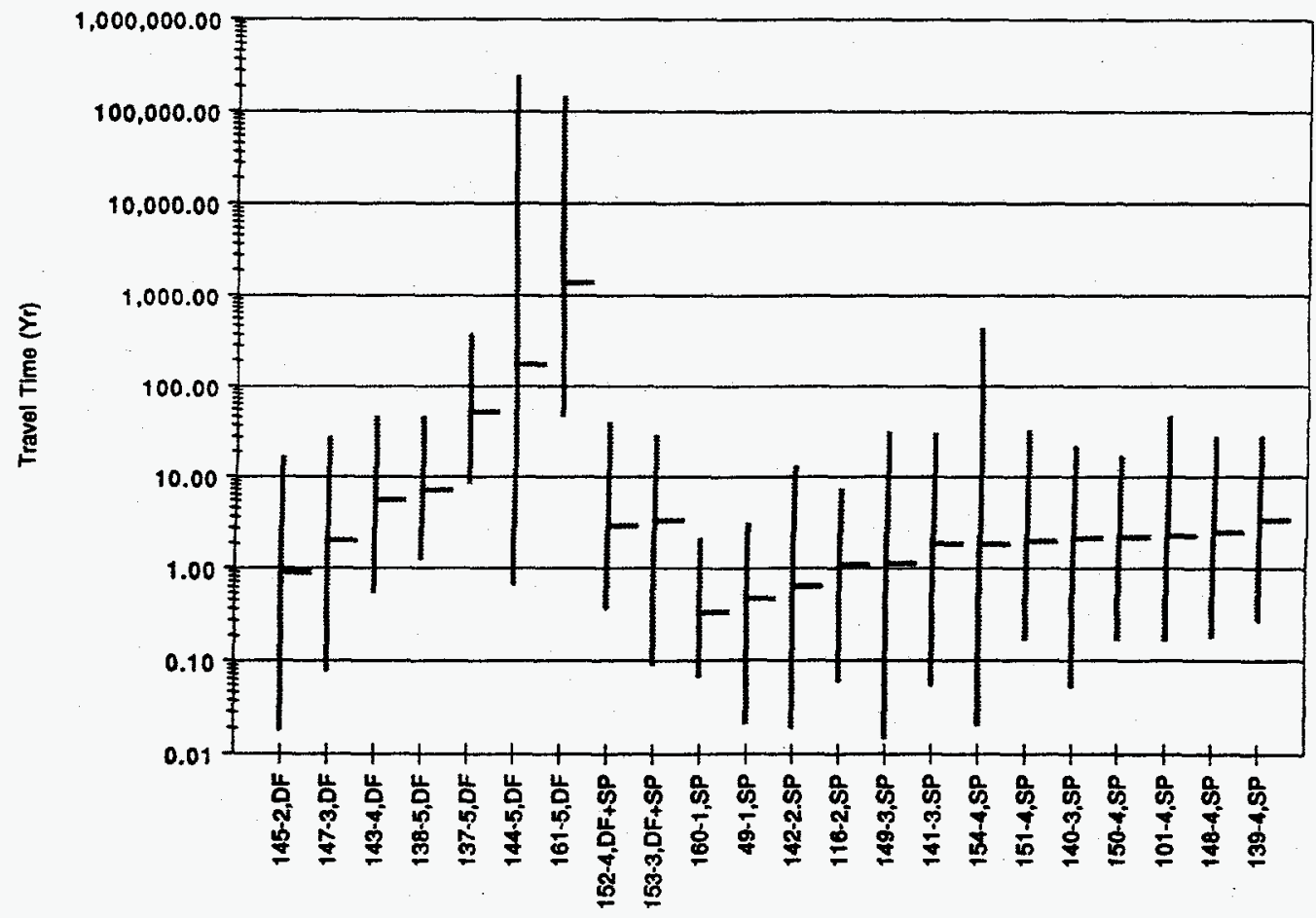

FIGURE 16. Ranking and the Minimum, Maximum, and Arithmetic Mean of the Travel Time for Seepage Pit and Drainfield Sites (ordered by geometry and mean travel time) 


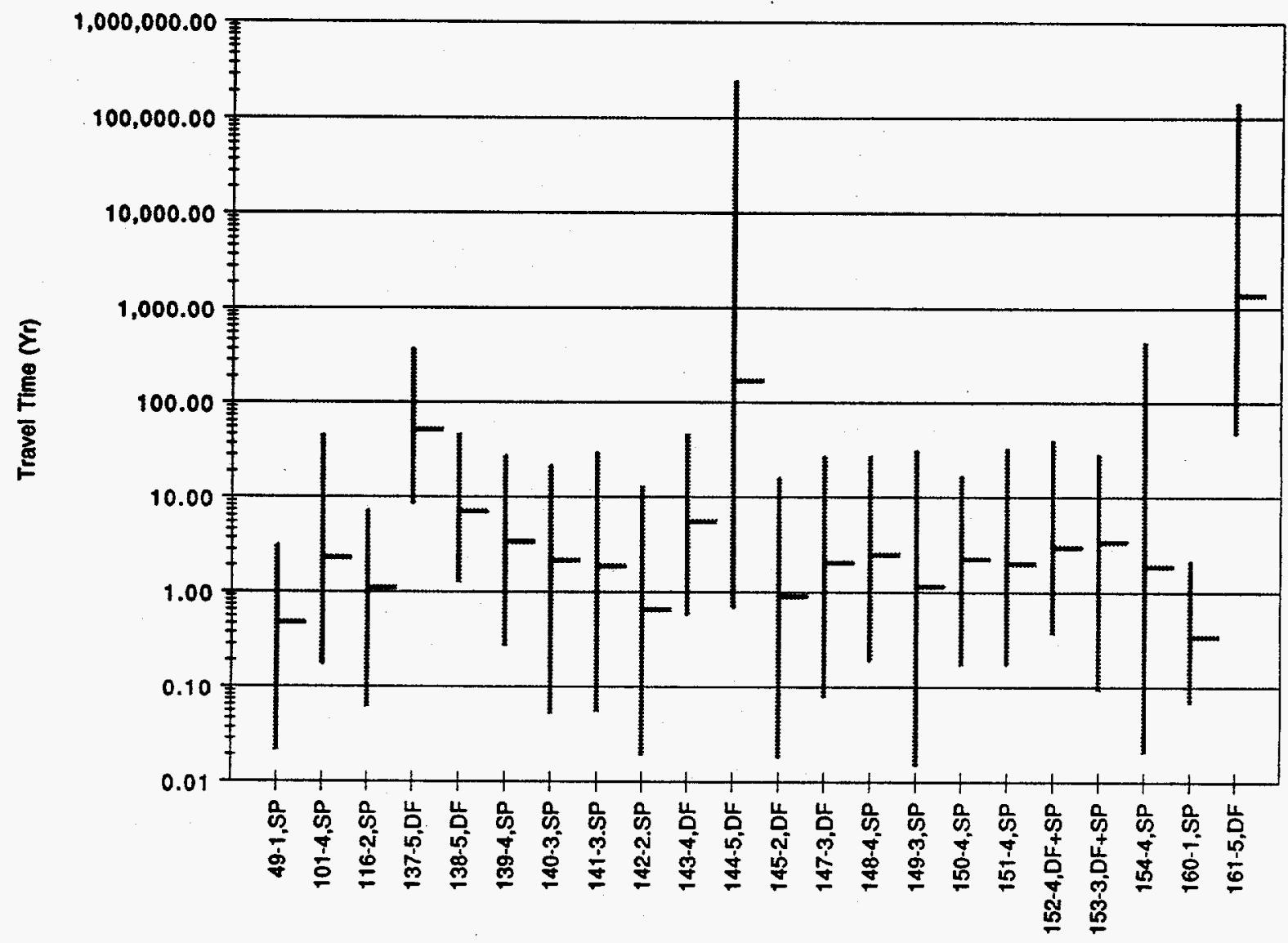

FIGURE 17. Ranking and the Minimum, Maximum, and Arithmetic Mean of the Travel Time for Seepage Pit and Drainfield Sites (ordered by the site number)

equation for transport (Healy, 1990). Two sets of calculations were completed, each using a different constant water usage rate. Thirty Monte Carlo calculations were performed within each set. The hydraulic properties were varied spatially for each calculation by using the TUrning Bands Algorithm (TUBA) (Zimmerman and Wilson, 1990); the spatial structure for the simulated property fields was modeled as imperfect layering as shown in Figure 18. Assumptions made in using the VS2DT model include the following:

- Van Genuchten's model (van Genuchten, 1980) of moisture content as a function of pressure head was assumed to be applicable; the van Genuchten parameter statistical distributions were inferred from SNL/NM site-specific data (Daniel B. Stephens \& Associates, Inc., 1990a,b; McTigue and Stein, 1990).

- Dispersivities were assumed constant with the longitudinal dispersivity specified at $20 \mathrm{~cm}$, and the transverse dispersivity specified at $2 \mathrm{~cm}$.

- Darcy's Law was valid.

- There was no water loss from the system via evapotranspiration.

- The infiltration rate applied to the model was constant. 


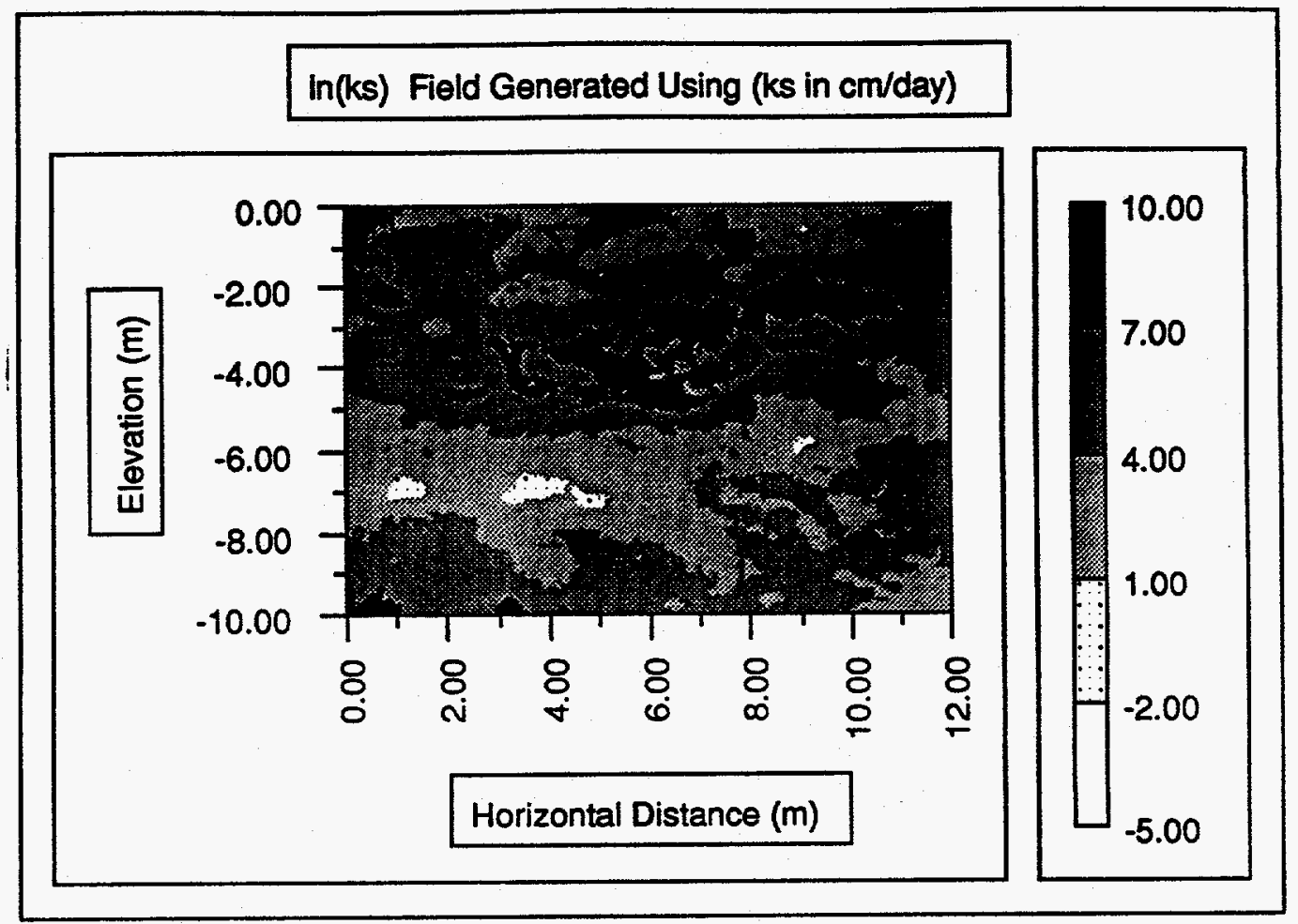

FIGURE 18. Example of the Two-Dimensional Spatial Variation in Hydraulic Conductivity Generated by TUBA

- The solute was conservative in that no retardation or decay was allowed.

The travel time results of the first model where the flux was limited by saturated hydraulic conductivity (the mass balance model) were compared with the VS2DT results. The results of this comparison are shown in Figures 19 and 20. Figure 19 shows the results at a water usage rate of approximately $10 \mathrm{gal} / \mathrm{day}$. Thirty runs from the first model were chosen for comparison with the VS2DT results. The water usage rates from the simple model ranged from 10.020 to $11.182 \mathrm{gal} / \mathrm{day}$. The travel time results from each method were first ordered from low to high and then paired for plotting. The results of this pairing are shown in Figure 19. In all cases, the VS2DT results were a factor of 1.7 to 4.5 times greater than the results from the simpler mass balance model.
Figure 20 shows the results at a water usage rate of approximately $50 \mathrm{gal} / \mathrm{day}$. The same process as that described above was used to obtain the paired results displayed in Figure 20. The water usage rates from the simple model range from 48.820 to $49.998 \mathrm{gal} / \mathrm{day}$. At this higher water usage rate, there appears to be slightly closer agreement between the two models, but the VS2DT results are still a factor of 2.0 to 3.9 times greater than the results from the simpler mass balance model.

\section{SUMMARY AND CONCLUSIONS}

Twenty-two of the twenty-three sites that are part of the STD activity are ranked on the basis of travel time from the septic structure to the water table. This ranking is a measure of the relative risk that each site may pose to human health and the environment. 


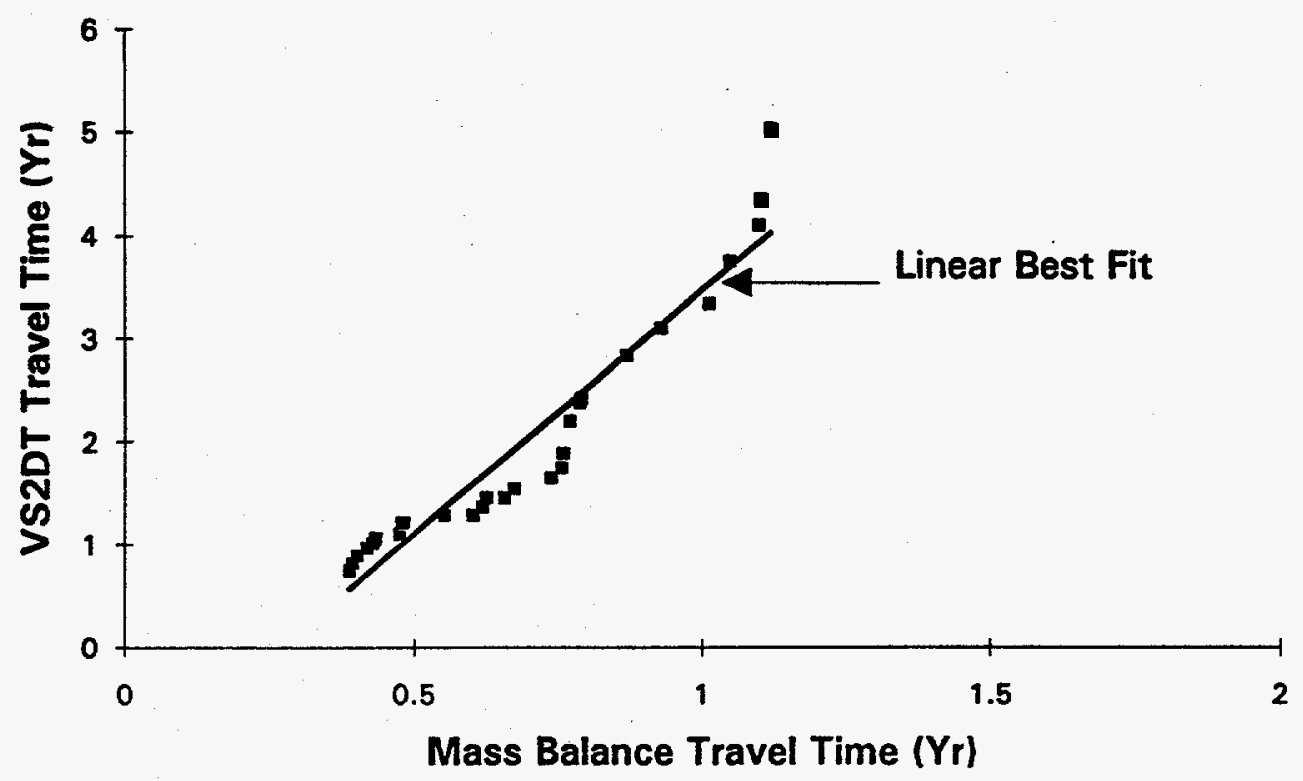

FIGURE 19. Comparison of VS2DT and Mass Balance Travel Time Results for a Water Usage Rate of Approximately $10 \mathrm{Gal} / \mathrm{Day}$

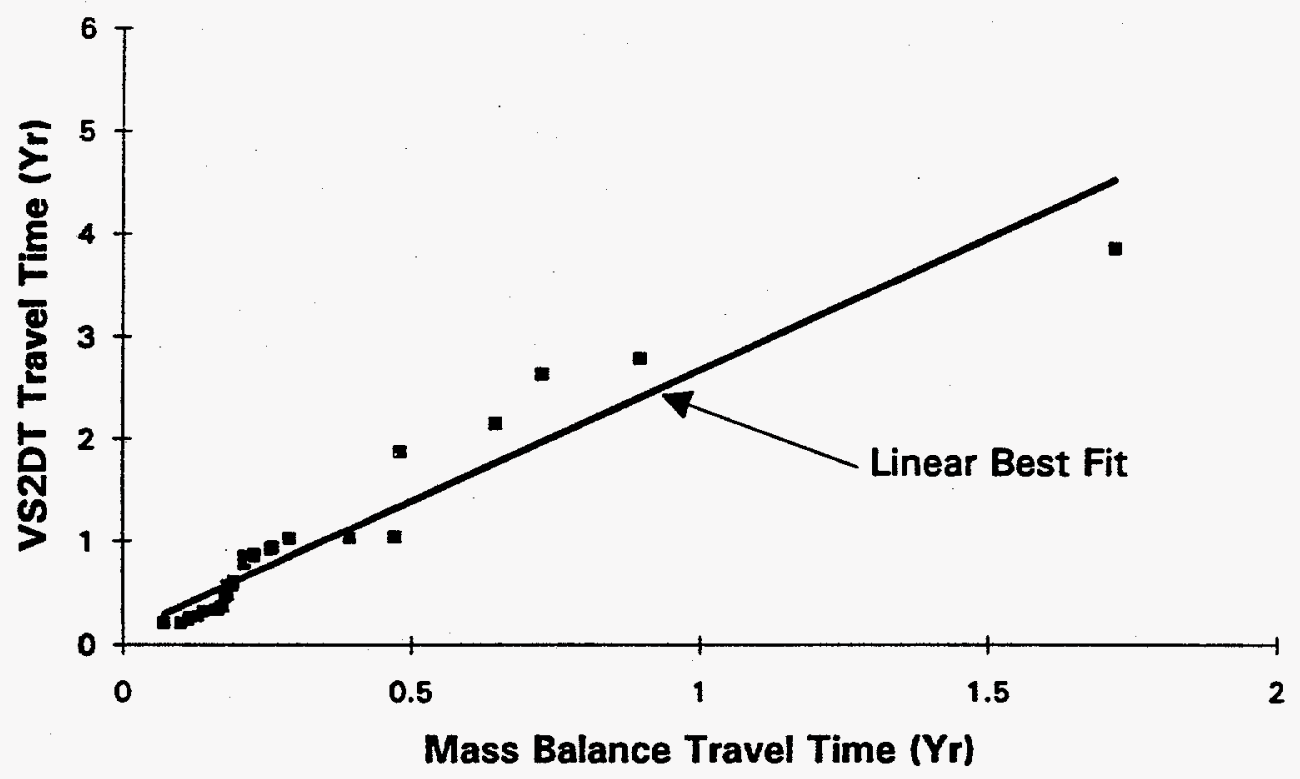

FIGURE 20. Comparison of VS2DT and Mass Balance Travel Time Results for a Water Usage Rate of Approximately $50 \mathrm{Gal} / \mathrm{Day}$

It is possible to name other risk criteria that could have been used, including the principal contaminants, the volume of contaminants disposed of, flow and transport charac- teristics of the contaminants through the sitespecific geologic media, and proximity to the receptors. The limited site-specific data on facility use derived from staff interviews 
about the contaminants to use the first three risk criteria, and the proximity to receptors, the last listed risk criterion, is nearly the same for all the sites considered. Thus, we decided to use the travel time from the septic structure to the water table to rank the sites.

The travel times used to rank the sites were calculated using a simple mass balance model with the calculated hydraulic conductivity (based on septic discharge and geometry) limited by a saturated hydraulic conductivity. The assumptions inherent in these calculations include piston flow, unit gradient, steady-state conditions, no retardation of contaminants, homogenous soil properties from the surface to the water table for a given realization, constant discharge from the septic system for a given realization, and porous media flow.

The 22 sites were divided into five priorities on the basis of the travel time from the septic structure to the water table. The differences in travel time between the first and the fifth priority sites are significant enough to indicate the potential for differences in risk to human health and the environment. However, the travel times (the mean, minimum, and maximum) for the remainder of the sites are so close in value that someone else could easily arrive at a different prioritization scheme if given the same data.

Some of the travel time results from the simple mass balance model were compared with those calculated using VS2DT, a twodimensional finite-difference code that solves Richard's equation for flow and the convection/dispersion equation for transport. The VS2DT travel times were a factor of 2 to $41 / 2$ times slower than the travel times predicted with the simple mass balance model. Thus, the simple mass balance results are expected to be more conservative than those that might be predicted by VS2DT. 


\section{REFERENCES}

Carsel, R.F., and R.S. Parrish, 1988. "Developing Joint Probability Distributions of Soil Water Retention Characteristics," Water Resources Research, Vol. 24, No. 5, pp. 755-769.

Crowson, D., J.D. Gibson, C.S. Haase, R. Holt, D. Hyndman, J. Krumhansl, F. Lauffer, J. P. McCord, J.T. McCord, D. Neel, A.M. Parsons and R. Thomas, October 1993, "Sandia National Laboratories Site-Wide Hydrogeologic Characterization Project Calendar Year 1992 Annual Report," SAND93-0681, Sandia National Laboratories, Albuquerque, NM, p. 4-31.

Daniel B. Stephens \& Associates, Inc., 1990a. "Laboratory Analysis of Soil Hydraulic Properties from the MW-4 CWL Monitoring Well," Daniel B. Stephens \& Associates, Inc., Albuquerque, New Mexico.

Daniel B. Stephens \& Associates, Inc., 1990b. "Laboratory Analysis of Soil Hydraulic Properties From the MW-4 CWL Monitoring Well (130.75 Feet to 253.33 Feet)," Daniel B. Stephens \& Associates, Inc., Albuquerque, New Mexico.

Freeze, R.A., and J.A. Cherry, 1979. Groundwater, Prentice-Hall, Inc., Englewood Cliffs, New Jersey.

Goodrich, M.T. Letter Report to Brenda Langkopf, "Estimating Contaminant Travel Time from a Septic Tank to a Shallow Water Table Under Uncertain Hydraulic Conditions," International Technical Corporation, January 1994.
Healy, R.W., 1990. "Simulation of Solute Transport in Variably Saturated Porous Media with Supplemental Information on Modification to the U.S. Geological Survey's Computer Program VS2D," WaterResources Investigations Report 90-4025, U.S. Geological Survey, Denver, CO.

Iman, R.L., and W.J. Conover, 1983. A Modern Approach to Statistics, John Wiley \& Sons, New York, New York.

Iman, R.L., and M.J. Shortencarier, 1984. "A FORTRAN 77 Program and User's Guide for the Generation of Latin Hypercube and Random Samples for Use with Computer Models," Sandia National Laboratories SAND83-2365, Albuquerque, New Mexico.

McCord, J.T., 1991. "Hysteresis and StateDependent Anisotropy in Modeling Unsaturated Hillslope Hydrologic Processes," Water Resources Research, Vol. 27, No. 7, pp. 1501-1518.

McTigue, D.F., and C.L. Stein to Distribution, Sandia National Laboratories, Albuquerque, New Mexico, January 16, 1990.

Otis, R.J., W.C. Boyle, E.V. Clements, and C.J. Schmidt, 1980. Design Manual: Onsite Wastewater Treatment and Disposal Systems, EPA-625/1-80-012, U.S. Environmental Protection Agency, Washington, DC.

Sandia National Laboratories (SNL), 1993. "Work Plan for the RCRA Facility Investigation of Septic Tanks and Drainfields (ADS-1295)," Sandia National Laboratories, Albuquerque, NM. 
Sandia National Laboratories (SNL), 1994. "Site-Wide Hydrogeologic Characterization Project - Calendar Year 1993 Annual Report," Sandia National Laboratories, Albuquerque, NM, pp. 4-22.

van Genuchten, R., 1980. "A Closed-Form Equation for Predicting the Hydraulic Conductivity of Unsaturated Soils," Soil Science Society of America Journal, Vol. 44, No. 5, pp. 892-898.
Zimmerman, D.A., and J.L. Wilson, 1990. "Description of and User's Manual for TUBA: A Computer Code for Generating Two-Dimensional Random Fields via the Turning Bands Method," SeaSoft, Albuquerque, NM. 


\section{APPENDIX A}

PROGRAM LISTING FOR THE MASS BALANCE CALCULATIONS WHEN VELOCITY IS NOT LIMITED TO SATURATED HYDRAULIC CONDUCTIVITY 


\section{Program Travel}

THIS PROGRAM CALCULATES THE GROUNDWATER TRAVEL TIME FROM THE SURFACE (OR FROM THE BOTTOM OF THE SEEPAGE PIT IF THE GEOMETRY OF CONCERN IS A SEEPAGE PIT) TO THE GROUNDWATER TABE. THE RATE OF TRAVEL IS DEPENDENT UPON THE CALCULATED RATE OF TRAVEL OF A SATURATED PLUG OF EFFLUENT. THE RATE OF TRAVEL IS BASED UPON A UNIT GRADIENT AND STEADY-STATE CONDITIONS. THERE IS NO RETARDATION OF THE EFFLUENT, NO EVAPORATION AND NO NATURAL RECHARGE. CONSTANT DISCHARGE FROM THE SEPTIC SYSTEM IS MODELED. THE SOIL PROPERTIES ARE HOMOGENEOUS FROM THE SURF.ACE TO THE WATER TABLE.

dimension dia (5), dpth (5)

data homin, hcmax $10.3,200.0 /$

string fnamet, fnameu, fname, sn

FILE NAMES

fnameT $=$ File of final numberical results (It includes the following information in the following order: groundwater travel time (TT), distance to the water table $(t)$, groundwater velocity $(v)$, volumetric daily water usage rate of one person (h20), and number of people (pn).)

fnameu $=$ File of interim results with a brief explanaiton of each result (This is called "unplotted information.")

fname $=$ File name of Latin hypercube input data

$A=0.0$

nopit $=0$

norem $=0$

nokmin $=0$

nokmax $=0$

depthl $=0$

c

CALCULATED VALUES

$\mathrm{VF}=$ volumetric flow in units of ft $3 /$ day

$v=$ calculated velocity in units of $\mathrm{ft} /$ day

$\mathrm{TT}=$ Travel time to the water table in units of years

INPUT CONSTANTS

Where

Idisp = integer field with values of 1 for seepage pit, 2 for drainfield or 3 for both seepage pit and drainfield

Dia = Diameter of seepage pit

$F t=$ Linear feet of drainfield

hcmin= Minimum saturated hydraulic conductivity in $\mathrm{ft} /$ day

hcmax= Maximum saturated hydraulic conductivity in $\mathrm{ft} /$ day

sn=site number

irep=number of repeated calculation to be done

dpth()=septic tank depth

depthl=largest septic tank depth

write $(*, *)$. Enter 1 for seepage pit, 2 for drainfield and 3 for both. read *, Idisp go to $(1,3,1)$ idisp

write $\left(*,{ }^{*}\right)$. How many seepage pits are there?'

read *, nopit

do $100 \mathrm{j}=1$, nopit

write $(*, *)$ 'Enter seepage pit diameter (in ft) '

read $(*, *)$ dia $(j)$

write $(*, *)$ 'Enter seepage pit depth (in ft) '

read $(*, *) \operatorname{dpth}(j)$

100 continue

$(j) \cdot g t \cdot$ depthl) depthl $=\operatorname{dpth}(j)$

write $(*, *)$ 'Enter linear footage of drainfield (in ft)

read $(*, *) \mathrm{Ft}$

5 write (*,*) 'Enter the site number '

read *, sn

write $(*, *)$ 'Enter the number of calculations to be done.

read $\star$, irep

C

INPUT LATIN HYPERCUBE VARIABLES 


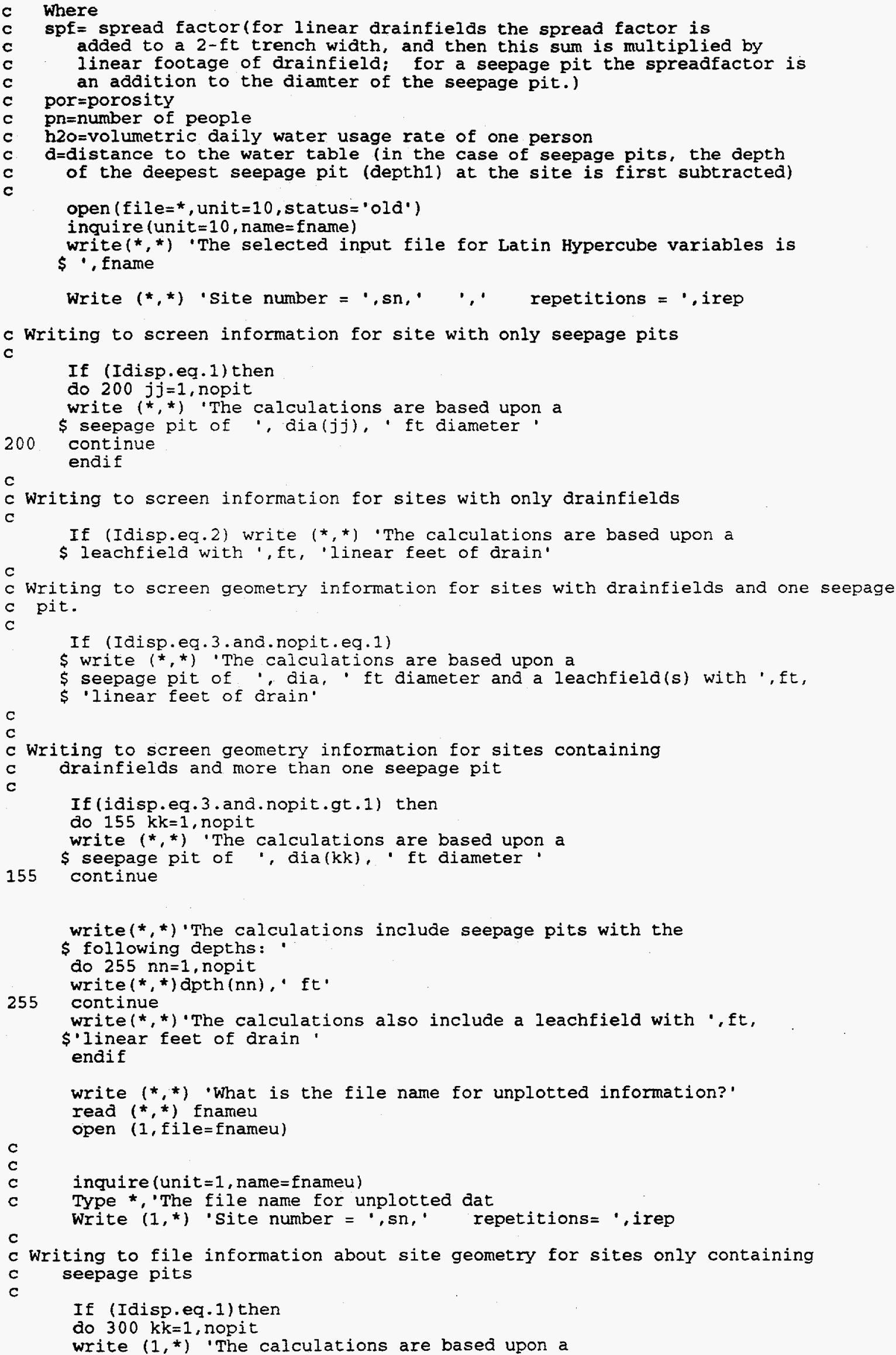


c

Writing to file information about site geometry for sites containing only drainfields

C

If (Idisp.eq.2) write $(1, *)$ 'The calculations are based upon a $\$$ leachfield with ', ft, 'linear feet of drain'

c writing to file information about site geometry for sites containing c drainfields and one seepage pit

If (Idisp.eq.3.and.nopit.eq.1) then

write $(1, *)$ The calculations include a seepage pit of ', \$ dia, - ft diameter and a leachfield with '. \$ft, 'linear feet of drain.

else

c Writing to file information about site geometry for sites containing drainfields and more than one seepage pit

C

If (idisp.eq.3.and.nopit.gt.1) then

do $350 \mathrm{kk}=1$, nopit

write $\left(1,{ }^{*}\right)$ "The calculations are based upon a

s seepage pit of ', dia $(k \mathrm{k})$, 'ft diameter. continue

write $(1, *)$ 'The calculations include seepage pits with the

$\$$ following depths:

do $400 \mathrm{nn}=1$, nopit

write $\left(1,{ }^{*}\right) \operatorname{dpth}(\mathrm{nn}),{ }^{\circ} \mathrm{ft}$

400 continue

write $(1, *)$ 'The calculations also include a leachfield with ',ft,

\$'linear feet of drain. endif endif

Write $(*, *)$ 'What is the file name for recording only travel time $\$$ data? "

read $(*, *)$ fnameT

$c$

open $(2$, file $=$ fnameT $)$

do $110 \quad n=1$, irep

$a=0.0$

read $(10, *)$ spf, por, pn, h20,d

write $(*, *)$ 'spf, por, pn, h20,d

write $(*, *)$ spf,por,pn, h2o,d

write $(1, *)$ 'spf, por, pn, h2o,d

write $(1, *)$ spf,por,pn, h20,d

Determine Area to be use in calculations

go to $(10,20,10)$ Idisp
do $500 \quad 11=1$, nopit
$A=A+(($ dia $(I I)+\operatorname{spf}) / 2) * * 2 * 3.14$

c $* * *$ Skip printing out area results beyond the first 20 calculations

c

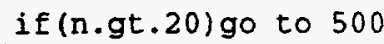

write $(*, *)$ 'Temporary area is ' A, 'ft2'

500 continue

If (Idisp.ne.3) go to 30

The drainfield area is calculated as the linear footage of drain multiplied by the sum of the spreadfactor and the 2-ft wide gravel-filled trench.

$20 \quad A=(f t *(\operatorname{spf}+2))+A$

C

$c \star \star * *$ skip printing out area results beyond the first 20 calculations

c

if (n.gt.20) go to 30 


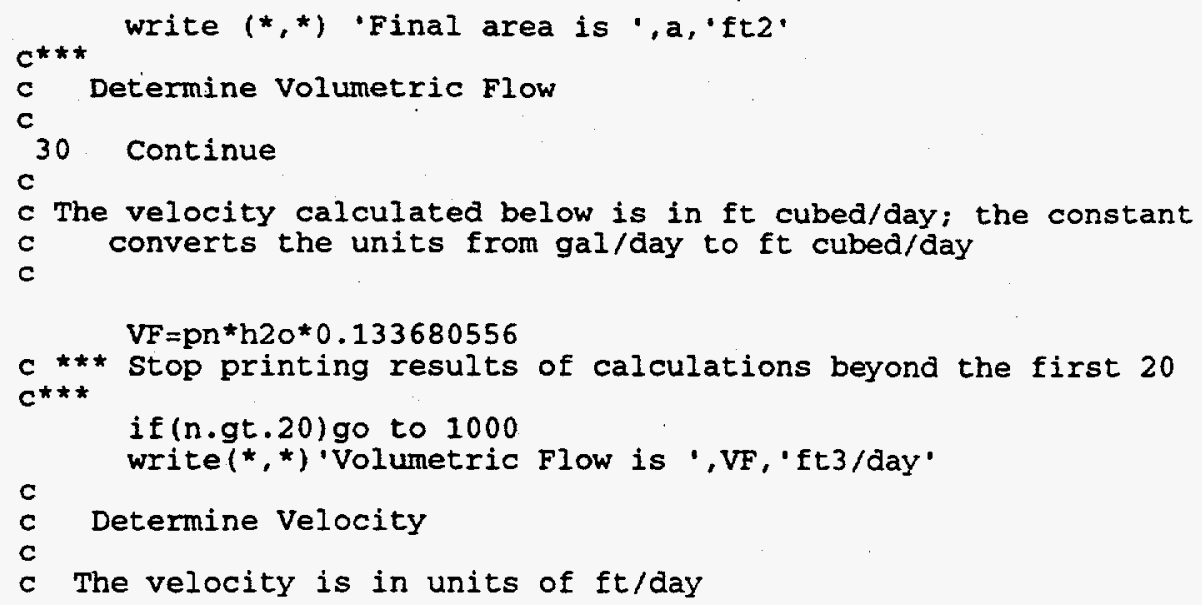


\$ an equivalent number of times as the velocity in the travel

\$ time calculations."

write $(1, *)$.The velocity used was greater than the minimum $\$$ hydraulic conductivity', nokmin, ' times,'

Write $(1, *)$ "The velocity used was greater than the maximum \$ hydraulic conductivity', nokmin, 'times. This value was used $\$$ an equivalent number of times as the velocity in the travel \$ time calculations.'

close (10)

close (1)

close (2)

end 


\section{APPENDIX B}

PROGRAM LISTING FOR THE MASS BALANCE CALCULATIONS WHEN

VELOCITY IS LIMITED BY SATURATED HYDRAULIC CONDUCTIVITY 
Program Travihe

C THIS PROGRAM CALCULATES THE GROUNDWATER TRAVEL TIME FROM THE SURFACE (OR FROM THE BOTTOM OF THE SEEPAGE PIT IF THE GEOMETRY OF CONCERN IS A SEEPAGE PIT) TO THE GROUNDWATER TABE. THE RATE OF TRAVEL IS DEPENDENT UPON EITHER A SATURATED HYDRAULIC CONDUCTIVITY DETERMINED FROM A LATIN HYPERCUBE SAMPLE FROM A LOGNORMAL DISTRIBUTION OR THE CALCULATED RATE OF TRAVEL OF A SATURATED PLUG OF EFFLUENT THE CALCULATED RATE OF TRAVEL IS BASED UPON A UNIT GRADIENT AND STEADY-STATE CONDITIONS. THERE IS NO RETARDATION OF THE EFFLUENT, NO EVAPORATION AND NO NATURAL RECHARGE. CONSTANT DISCHARGE FROM THE SEPTIC SYSTEM IS MODELED. THE SOIL PROPERTIES ARE HOMOGENEOUS FROM THE SURFACE TO THE WATER TABLE.

dimension dia(5), apth (5)

data homin, homax $10.3,200.0 /$

string fnamet, fnameu, fname, sn

FILE NAMES

fnameT $=$ File of final numberical results (It includes the following information in the following order: groundwater travel time (TT), distance to the water table $(t)$, groundwater velocity $(v)$, volumetric daily water usage rate of one person (h2o), and number of people (pn).)

fnameu $=$ File of interim results with a brief explanaiton of each result (This is called "unplotted information.")

fname $=$ File name of Latin hypercube input data

$A=0.0$

nopit $=0$

norem $=0$

nokmin $=0$

nokmax $=0$

depthl=0

ihc $=0$

\section{CALCULATED VALUES}

$\mathrm{VF}=$ volumetric flow in units of ft3/day vcalc = calculated velocity in units of ft/day

$v=$ velocity used to calculate the travel time. This value was the minimum of the calculated velocity and the Latin Hypercube sample of the the saturated hydraulic conductivity. The units are ft/day.

$\mathrm{TT}=$ Travel time to the water table in units of years

INPUT CONSTANTS FOR A GIVE SITE

Where

Idisp = integer field with values of 1 for seepage pit, 2 for drainfield or 3 for a combination seepage pit and drainfield

Dia = Diameter of seepage pit

$\mathrm{Ft}=$ Linear feet of drainfield

hcmin= Minimum saturated hydraulic conductivity in ft/day

hcmax = Maximum saturated hydraulic conductivity in $\mathrm{ft} /$ day

sn=site number

irep=number of calculations to be done

apth()=septic tank depth

depthl=largest septic tank depth

nopit $=$ number of seepage pits

write $(*, *)$ 'Enter 1 for seepage pit, 2 for drainfield and 3 for both read * Idisp

go to $(1,3,1)$ idisp

read *, nopit

do $100 j=1$, nopit

write $(*, *)$ 'Enter seepage pit diameter (in ft) '

read $(*, *)$ dia $(j)$

write $(*, *)$ 'Enter seepage pit depth (in ft).

read $(*, *)$ dpth $(j)$

if $(\operatorname{apth}(j) \cdot g t \cdot \operatorname{depth} l) \operatorname{depthl}=\operatorname{dpth}(j)$

100 continue

if (idisp.eq.1)go to 5

3 write $(*, *) \cdot$ Enter linear footage of arainfield (in $f t$ ).

read $(*, *) \mathrm{Ft}$

5 write $\left({ }^{*},{ }^{*}\right)$ 'Enter the site number. 


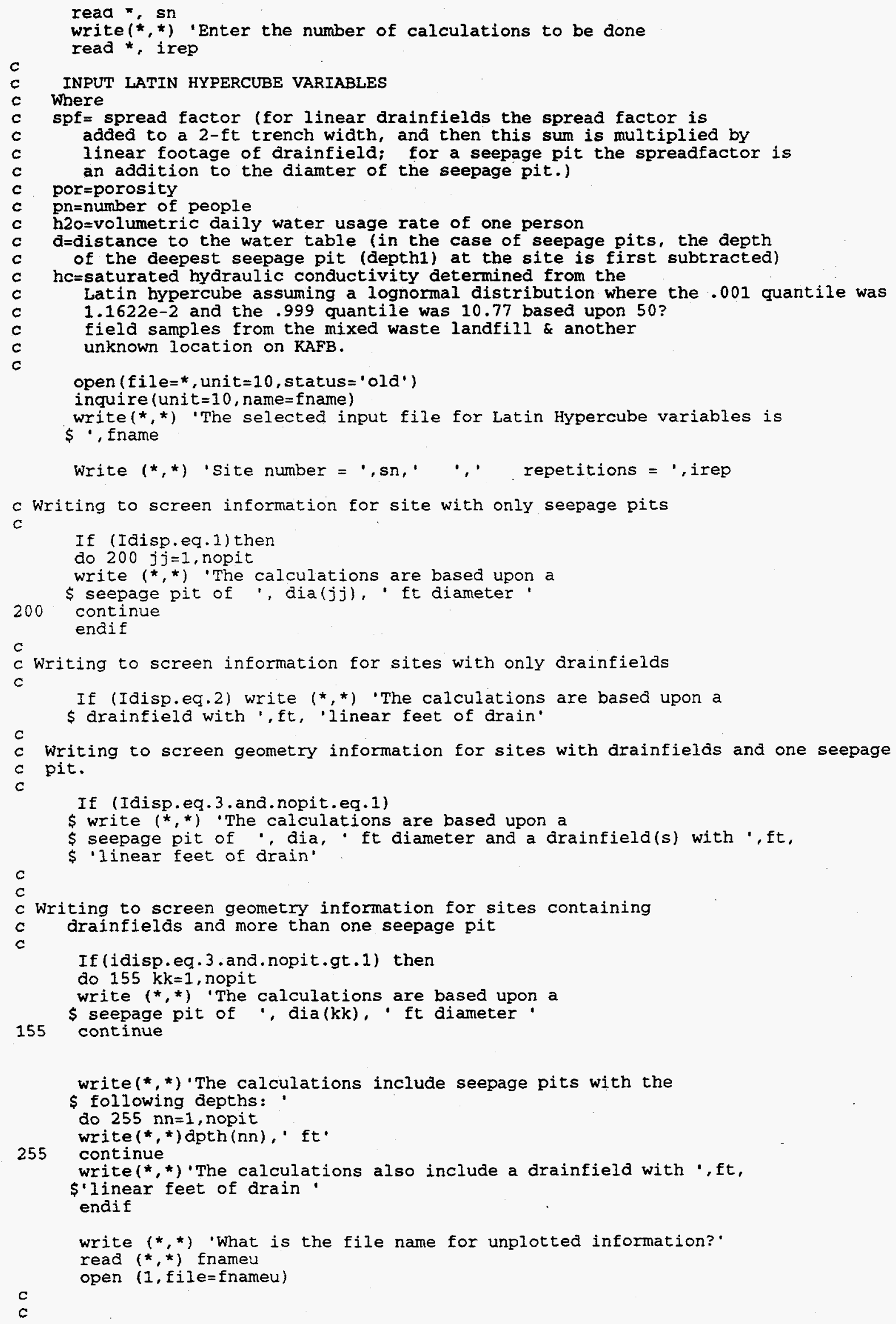




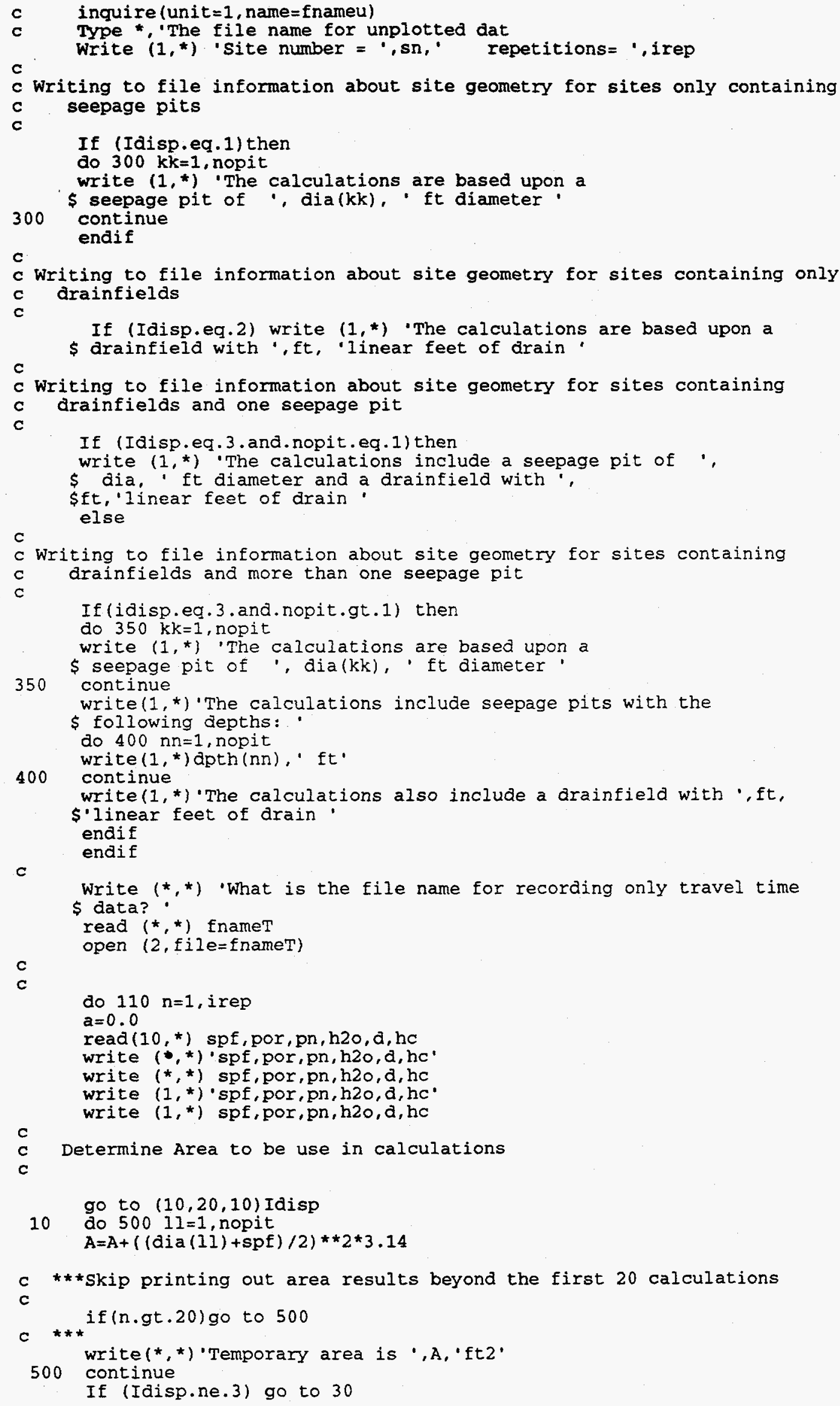


Write $(*, *)$ 'Volumetric water usage was $=$ ',h2o,' gal/day'

write $(*, *)$.The distance from the surface to the water table is. $\$, d, ' f t$ '

If (idisp.eq.1.or.idisp.eq.3) then

write $(*, *)$ 'The largest seepage pit was ', depthl,' ft deep'

write $(*, *)$ "The distance to the water table used in this

$\$$ calculation $=$ ", tdepth, $\mathrm{ft}$ '

endif

write $(*, *)$ 'Travel time for this calculation was $=$ ', tt,' years' write $(1, *)$ 'The distance from the surface to the water table is s, $\mathrm{d}, \mathrm{ft}$

If (idisp.eq.1.or.idisp.eq.3) then

write $(1, *)$ 'The largest seepage pit depth was ',depthl, 'ft'

Write $(1, *)$ 'Distance to water table in this calc $=$ '. tdepth, 'ft' endif

Write $(1, *)$ 'Number of people used in this calculation $=$ ', pn

Write $(1, *)$ 'volumentric water usage was $=, \mathrm{h} 20,{ }^{\circ} \mathrm{ft} /$ day'

Write $(1, *)$

Write $(2, *)$ tt, $d, v, h 20, p n$

Write $(*, *)$ 'The velocity used was greater than the minimum

$\$$ hydraulic conductivity ' nokmin, ' times,'

write $(*, *)$ "The calculated velocity was greater than the maximum

$\$$ hydraulic conductivity ', nokmax, ' times.' write $\left(* *^{*}\right)$. The velocity used was less than the calculated $\$$ hydraulic conductivity' ' ihc, ' times. This value was used $\$$ an equivalent number of times as the velocity in the travel \$ time calculations.'

write $\left(1,{ }^{*}\right)$ 'The velocity used was greater than the minimum

$\$$ hydraulic conductivity' nokmin, ' times,'

Write $(1, *)$.The velocity calculated was greater than the maximum $\$$ hydraulic conductivity $\cdot$, nokmin, ' times. Write $(1, *)$. The velocity used was less than the calculated

s hydraulic conductivity' ihe, 'times. This value was used

$\$$ an equivalent number of times as the velocity in the travel

s time calculations.

close (10)

close (1)

close (2)

end 


$\begin{array}{rll}\text { DISTRIBUTION } & \\ 4 & \text { MS-0184 } & \text { U.S. Department of Energy } \\ & & \begin{array}{l}\text { Attn: John Gould } \\ \text { P.O. Box 5400 } \\ \text { Albuquerque, NM 87185-5400 }\end{array} \\ & & \\ 1 & \text { MS-1309 } & \text { Environmental Operations Records Center, 7500 } \\ 1 & \text { MS-1311 } & \text { Ward, Steve, 7511 } \\ 1 & \text { MS-1347 } & \text { Cox, Warren, 7581 } \\ 1 & \text { MS-1347 } & \text { Nimick, Fran, 7582 } \\ 1 & \text { MS-1347 } & \text { Roybal, Tony, 7582 } \\ 1 & \text { MS-1347 } & \text { Miller, David, 7582 } \\ 1 & \text { MS-1347 } & \text { Conway, Rarilee, 7582 } \\ 1 & \text { MS-1347 } & \text { Aas, Chris, 7582 } \\ 1 & \text { MS-1347 } & \text { Dawson, Lon, 7582 } \\ 1 & \text { MS-1348 } & \text { Fernandez, Joe, 7583 } \\ 1 & \text { MS-1348 } & \text { Fate, Dick, 7585 } \\ 1 & \text { MS-1348 } & \text { Ardito, Cindy, 7585 } \\ 1 & \text { MS-1348 } & \text { Peace, Jerry, 7585 } \\ 1 & \text { MS-1348 } & \text { Byrd, Caroline, 7585 } \\ 1 & \text { MS-1348 } & \text { Lojek, Carole, 7585 } \\ 1 & \text { MS-1348 } & \text { Laursen, Eric, 7585 } \\ 1 & \text { MS-1350 } & \text { Stermer, Dorothy, 7584 } \\ 1 & \text { MS-1350 } & \text { Collins, Sue, 7584 } \\ 10 & \text { MS-0727 } & \text { Langkopf, Brenda, 6622 } \\ 5 & \text { MS-0727 } & \text { Galloway, Bob 6622 } \\ 3 & \text { MS-0727 } & \text { McCord, Jim, 6622 } \\ 1 & \text { MS-9018 } & \text { Central Technical Files, 8523-2 } \\ 5 & \text { MS-0899 } & \text { Technical Library, 13414 } \\ 1 & \text { MS-0619 } & \text { Technical Publications, 13416 } \\ 10 & \text { MS-1119 } & \text { Document Processing for DOE/OSTI, 7613-2 } \\ & & \end{array}$

